\title{
BIM in Off-site Manufacturing for Buildings
}

\author{
${ }^{1}$ F.H. Abanda, ${ }^{2}$ J.H.M. Tah and ${ }^{3}$ F.K.T. Cheung \\ ${ }^{1,2}$ School of the Built Environment \\ Oxford Brookes University \\ Oxford, United Kingdom \\ ${ }^{3}$ School of Engineering and the Built Environment \\ Birmingham City University \\ Birmingham, United Kingdom
}

\begin{abstract}
The need to overcome challenges faced by construction industry has been at the core of many government reports. Most of the reports suggest the adoption of innovations including off-site manufacture and emerging Building Information Modelling (BIM) to overcome the challenges facing the industry. Current research has largely focused on the impacts of off-site manufacture and BIM independently applied on traditional construction methods. Due to the factory-based nature of off-site manufacture, the benefits of BIM on off-site manufacture have been widely argued to be far greater than those of traditional construction. However, studies about impacts of BIM on off-site manufacture are scarce with far too many on traditional construction. This study investigates the implications of BIM systems on off-site manufacture and traditional construction methods, with emphasis on the technological potential of BIM for off-site manufacture. The specific objectives of the study are threefold. Firstly, it examines how BIM can support off-site manufacture. Secondly, the paper discusses the benefits of BIM and explains how BIM can overcome barriers hindering the uptake of off-site manufacturing. Thirdly, due to the importance to measure the benefits to support wider adoption, an examination of the published quantitative benefits of BIM on off-site manufacture and traditional construction is undertaken. A critical appraisal of the literature was undertaken to achieve the aim of this study. The main findings are the identification of qualitative and quantitative benefits of: BIM on off-site manufacture, off-site manufacture and BIM on traditional construction. The findings reinforce the argument that BIM adoption on off-site manufacturing projects is a rapid, efficient and one of the best ways to improve on the long standing challenges that have plagued the construction industry for generations.
\end{abstract}

Keywords: BIM, challenges, construction industry, off-site manufacture, performance 


\section{Background}

The construction industry has been criticised for being inefficient; often generating too much waste, emitting significant amounts of greenhouse gases and consuming too much energy compared to other industries. In both the public and private sectors, it is not uncommon to find projects far exceeding budgets and deadlines. While such a characterisation of the construction industry may slightly differ with different countries, the trend is largely similar. Therefore, the need for innovation, e.g. BIM and off-site manufacture to improve performance in the global construction industry is the same and has been long overdue. Consequently, while most of the discussions here will focus on the UK context, to gain other insights and perspectives, examples will be drawn from developed and developing countries Sawhney et al. (2014) argued that the sector is confronted by numerous inefficiencies like time and cost overruns, and irregularities in procurement. These inefficiencies vary from country to country due to many factors including environmental, topographical, technological and social constraints. Most developing countries experience cost overruns exceeding 100\% of the initial project budget (Memon et al., 2013). In Australia, Love (2002) found rework contributed to $52 \%$ of a project's cost growth and that $26 \%$ of the variance in cost growth was attributable to changes due to direct rework. In Malaysia, approximately $75 \%$ of projects procured traditionally incurred overruns of $10 \%$ or more while the corresponding proportion for construction management and design-build was approximately two-thirds (Shedu et al., 2015). In the UK, the cost of Wembley stadium overran by 50\%; the Scottish parliament building had a time overrun of more than 3 years and a cost overrun of $900 \%$ (Love et al., 2011). Based on mean percentage overrun in Malaysia, an overrun of $38 \%, 39 \%$ and $50 \%$ time overruns were experienced on infrastructure projects, health and office projects respectively (Shehu et al., 2015). In Hong Kong, the average time overrun is 9\%, 17\%, and $14 \%$ for public building, private building and civil engineering projects respectively (Shehu et al., 2015).

Through various government commissioned studies, performance targets have been proposed to improve the delivery of projects. The UK Construction Strategy 2025 is amongst the most recent government reports that require the industry to dramatically improve its performance in four key areas by 2025. These areas include lowering greenhouse gas emissions in the built environment by $50 \%$, reducing the initial cost of construction and the whole life cost of built assets by $33 \%$, reducing the overall time, from inception to completion, for new-build and refurbished assets by $50 \%$ and improving exports by $50 \%$. Achieving these targets is quite a huge challenge, especially given the long standing fragmented nature and adversarial culture of the industry that have hindered any meaningful progress for generations. Thus, there have been calls for multiple complementary innovative initiatives to drive efficiency and improvement in the industry for quite some time now. Two main areas that the UK government identified as opportunities to drive efficiency and improvement to the construction industry are first, moving operations off-site according to Egan (1998) and second, the implementation of Building Information Modelling (BIM) strategy published by Cabinet Office (2011) in the UK. The most recent industry report, titled "Modernise or Die", commissioned by the UK Construction Leadership Council published in October 2016 strongly recommended the uptake of off-site manufacturing and BIM in order to improve the performance of the construction industry (Farmer, 2016).

The benefits of off-site manufacturing have been well-explored (e.g. Lawson et al. 2005; Lawson et al. 2014; Li et al. 2016a; Kamali and Hewage 2016; Tam et al. 2015; Patlakas et al. 2015a). Common arguments for the off-site manufacturing choice over traditional 
construction on site according to the literature include improved quality, good health and safety and better working conditions, higher tolerances, lower costs and reduced labour reworks, lower construction waste, simplified construction processes, products that are factory tried and tested, predictable sustainability performance, better control and consistency in products and processes. Emerging BIM provides opportunities to leverage these benefits. It has been argued that the biggest growth in construction productivity will come from automated off-site activities that are facilitated by BIM (Goulding et al., 2012). In spite of this, studies about impacts of BIM on off-site manufacturing are scarce. Benefit realisation has been one of the current topics about BIM; but most studies are set on the basis of traditional construction. The few studies that exist about BIM for off-site manufacturing often focus on explaining the qualitative benefits. Understanding the measurable benefits in implementing BIM in off-site manufacturing could significantly improve its adoption and efficiency.

The remainder of this paper covers 8 different aspects of the study. Firstly, a clear problem statement is presented. Following from the problem statement, the method employed is presented. Thirdly, to facilitate understanding, definitions and related concepts of off-site manufacturing and BIM have been examined. This culminated in the establishment of the synergy between BIM and off-site manufacturing. Fourthly, building on this synergy, an overview of some key BIM systems highly relevant to off-site manufacturing is presented. The drivers for both off-site manufacturing and BIM, with emphases on the qualitative and quantitative benefits of BIM to off-site manufacturing and traditional construction methods have been examined. Also, the findings and implications of this study have been reported. Lastly, the conclusion of this study is done by a way of summary with perspectives on future research discussed.

\section{Problem statement}

An extensive literature review was undertaken to identify the gap that underpins this study. The focus of the review was on BIM applied on off-site manufacturing. The review yielded issues related to methods of BIM deployment, ease of applications, comparative studies and benefits of BIM in off-site manufacturing. Firstly, some studies examined the 'methods' of how BIM can be used in modelling and managing off-site manufactured buildings. Samarasinghe et al. (2015) proposed a framework that illustrates how different BIM software systems have been used in the modelling of a prefabricated house in the different phases of the construction life cycle. Sebastian et al. (2009) examined how BIM can be used to guide how the prefabricated components should be put together to form a building. Secondly, some studies focused on the 'ease' of incorporation of off-site manufacturing and collaboration early on in the design and construction process using BIM. Cowles and Warner (2013) argued that the use of BIM made it more effective to incorporate prefabrication and collaboration early on in the design and construction process. Thirdly, some studies focused mostly on 'comparing' traditional with off-site manufacturing and/or BIM 'benefits' to traditional or off-site manufacturing. Alaghbari et al. (2007) argued that off-site manufacturing reduces delays in delivery of construction projects. Babič et al. (2010) argued that the introduction of BIM into the industrialized process can be considered easier than in the case of traditional construction. This is because industrial or prefabricated components can be developed into standardised BIM objects that can be stored in a BIM object library and re-used in design later in future. While in traditional construction most building parts are produced onsite from its constituent materials and can only be designed in real time from 
scratch without the possibility of picking any existing ones from any repository. Nadim and Goulding (2011) expanded on this by producing a table that compares off-site manufacturing and traditional construction. On the other hand, some studies simply state the 'benefits' of BIM in off-site manufacturing without necessarily comparing with traditional construction. Mitchell and Keaveney (2013) argued that the implementation of a BIM system will increase the efficiency of Irish contractors on design and build projects in terms of reducing man hours, requests for information and rework, increasing on time completions and the ability to use more prefabricated elements.

This paper analysed previous studies according to a) the areas of improvement and a) the extent of improvement to develop an understanding of the benefits. The areas of improvement reported include structural appraisal (Oti et al., 2016), the impact of building orientation on energy consumption (Abanda and Byers, 2016), monitoring of schedule risk (Musa et 2016; Musa et al. 2015; Li et al., 2016b), assessment of impact of occupants' on energy consumption (Abanda and Cabeza, 2015), construction safety management (Chan et al., 2016; Malekitabar et al., 2016), waste minimisation through deconstruction (Akinade et al., 2015), project planning (Liu et al., 2015), embodied energy assessment (Shadram et al., 2016). The extent of improvement has been widely reported with more studies only suggesting the benefits generically rather than systematically. Some examples (Doumbouya et al., 2016; Ismail et al. 2016) have listed so many benefits without any critical appraisal. For the studies that include measurement of the benefits either using a qualitative or quantitative approach, there is hardly a focus to distinguish whether the benefits are applicable to off-site manufacturing or traditional construction. As an example, Guo and Wei (2016) conducted an operational energy analysis of a building in National Taiwan University using BIM without explicitly stating whether the building was traditionally constructed or off-site manufactured. Furthermore, benefits using a qualitative approach are typically subjective and are limited to comparing the performance parameters of BIM. Quantified benefits can be used to overcome the preceding challenge associated but capturing measurable variables is a huge challenge (Zhang et al., 2016). Perhaps partly because of the limitation in capturing measurable variables, studies that show quantified benefits are scarce. To surmise, what emerges from the preceding discussion is a distinct knowledge gap in the alignment of BIM and off-site manufacture that reveals the quantitative benefits of the former on the latter. Quantitative assessments allow for objective evaluations of attributes to be undertaken while the results are comparable (Wong et al., 2007). In a recent study by Steinhardt and Manley (2016), it was argued that quantitative data allows a systematic comparison of the adoption of prefabrication by selected countries.

\section{Research methods}

This study investigates the use of BIM in leveraging the benefits of off-site manufacturing and further examines the quantitative benefits of BIM on both off-site manufacturing and traditional construction methods. The research framework used to achieve the aim of this study is illustrated in Figure 1. 


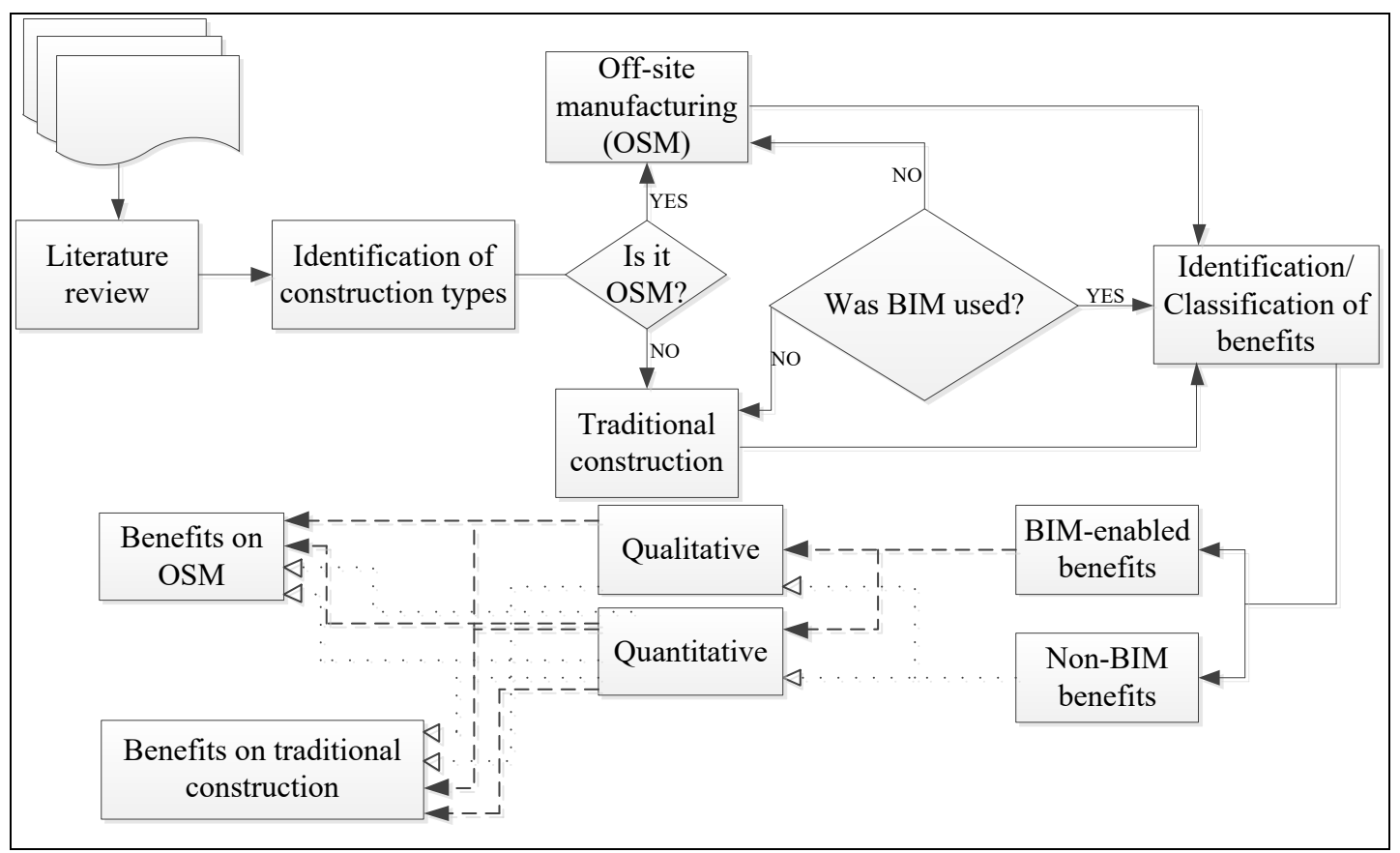

Figure 1: Research framework

Based on Figure 1, five-step process is pursued to achieve the objectives of this study. The first step consists of identifying relevant articles about BIM benefits on traditional and/or offsite manufacturing. To this end, searches using smart key phrases were conducted in renowned peer-reviewed databases such as ScienceDirect, Emerald and Google Scholar. The key phrases used are "BIM for traditional construction", "BIM for conventional construction" and "BIM for off-site manufacturing. To maximise the search results, key phrases around related terms or synonyms to 'off-site manufacture', e.g. off-site construction, pre-assembly (see section 4) were also used in identifying literature about the benefit of BIM on off-site manufacturing. In the second step, each article was read and determined whether it was about off-site manufacture or traditional construction (see smaller decision operation symbol in Figure 1). Furthermore, a detail read of the articles was undertaken to establish whether BIM was used in any aspect in the construction type (see larger decision operation symbol in Figure 1). In the third step, the articles were screened for relevance with focus on those that discussed the benefits of BIM for traditional construction and/or off-site manufacturing (i.e. BIM-enabled benefits) and other benefits of off-site construction over traditional construction not resulting from BIM, called non-BIM benefits. Fourthly, the articles were classified according to whether the content was about qualitative, quantitative benefits or both. Lastly, based on the preceding step, the articles were now classified according to benefits types (qualitative and quantitative) versus construction types (off-site manufacturing or traditional construction). The articles were mostly peer-reviewed journal and conference papers.

\section{Off-site manufacturing}

After the First and Second World wars, there was a significant shortage of labour and building materials. This stimulated research in innovative methods of construction such as off-site manufacturing for delivering affordable housing. Since then, different nomenclatures have been used, albeit interchangeably for off-site manufacturing. These include off-site industrialisation (Zhai et al., 2014), manufactured construction (Arif and Egbu, 2010), off-site fabrication, off-site construction, pre-assembly, pre-fabrication, pre-work, modern methods 
of construction, system building, non-traditional building, industrialised buildings, standardised buildings and open building manufacturing (Pan et al. 2012; Yunus and Yang, 2012; Yunus and Yang, 2014; Nadim and Goulding, 2011; Steinhardt and Manley, 2016), factory produced/manufactured buildings (Christoforou et al., 2016), modularisation (Linner and Bock, 2012; Oesterreich and Teuteberg, 2016; Isaac et al. 2016), pre-manufacture (Farmer, 2016). There are minor differences and context of use between these appellations. Their detail examination is out of the scope of this study. For consistency purposes, the general term 'off-site manufacturing' will be used. A recent study by the Construction Industry Council defines off-site manufacturing as a delivery method that adds substantial value to a product and process through factory manufacture and assembly intervention (Miles and Whitehouse, 2013). The main types of off-site manufacturing are panellised, volumetric, hybrid, modular systems and components $\&$ sub-assembly systems. To facilitate understanding, some other sub-concepts of off-site manufacturing discussed in Abanda (2011) are presented in Figure 2. It is important to note that similar concepts off-site manufacturing have been examined in Ross (2005) and Hairstans (2010).

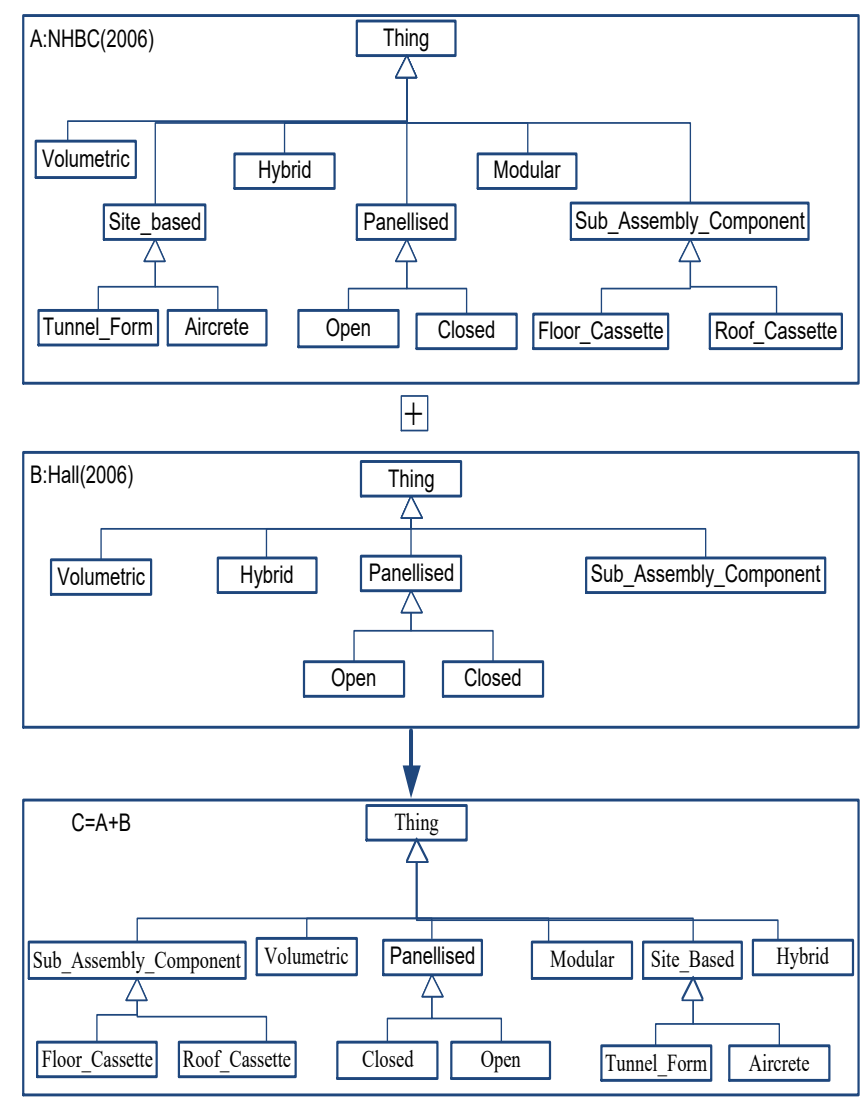

Figure 2: A generalised ontology of off-site manufacturing concepts [Source: reported by Abanda (2011)]

Panellised systems are factory-produced flat panel units assembled onsite to produce the 3dimensional (3D) structure. The volumetric systems are factory-produced 3D units that enclose usable space but do not form the building structure, e.g. bathroom pods, plant rooms, lift shafts, etc. Volumetric systems are also known as non-structural volumetric spaces (Steinhardt and Manley, 2016). The hybrid system is a combination of both the volumetric and the panellised units/systems. Modular buildings are pre-assembled volumetric units that together form the whole building (e.g., hotel modules) (Pan et al., 2012). In some circumstances they might be additional on-site works on modular buildings such as external brick skin and tiled roof. Components $\&$ sub-assembly systems are factory-produced items 
not regarded as full systems but they replace parts of the structure normally fabricated onsite. Regardless of the appellation used, the ultimate goal of the technique is to accrue benefits such as a reduction in construction time, construction waste, material waste, energy consumption, labour demands and cost, and an improvement in project constructability and cost certainty (Zhai et al., 2014; Patlakas et al., 2015b). After providing an overview of offsite manufacturing, a definition of BIM is examined in section 5.

\section{Building Information Modelling}

Building Information Modelling (BIM) is being hailed as a solution to overcome age old challenges often associated with traditional working practices in the construction industry. BIM has been defined differently by different organisations. In the US, it has been defined by leading organisations such as the National BIM Standard-United States ${ }^{\mathrm{TM}}$ (NBIMS, 2015), American Institute of Architects (AIA undated). In the UK, the joint definition from Royal Institute of British Architects (RIBA), Construction Project Information Committee (CPIC) and buildingSmart states "BIM as a digital representation of physical and functional characteristics of a facility creating a shared knowledge resource for information about it forming a reliable basis for decisions during its life cycle, from earliest conception to demolition". This definition is widely used amongst professionals.

This study acknowledges the subtle differences between the various definitions and their context of applications, which, nonetheless, are outside the scope of the study. However, what is common in all the definitions is BIM being acknowledged as a process, where BIM software systems as technologies are enhancers of the processes. As a system or technology, BIM is used to foster collaboration amongst project teams and sharing of project information. Enhancing collaborative processes using BIM systems has the potential to (i) increase productivity, efficiency, infrastructural value, quality and sustainability; (ii) reduce lifecycle costs, lead times and duplications; (iii) minimise or eliminate waste; and (iv) improve coordination between design disciplines (Ciribini et al., 2016). The strength of BIM systems is inherent in the fact that construction consultant can construct a project in a virtual environment before contractors can begin to construct it in reality (Vernikos, 2012). By having the possibility to build the whole project virtually before physical construction begins, BIM adds a level of accuracy to both quantity and quality issues that overcome shortcomings found when traditional design methods are used (Zhang et al., 2016). This offers the possibility to make informed decisions in a virtual environment based on the results of various iterations. The Cookham Wood Prison in Kent is an example where informed decisions have been made virtually to improve design (The HM Government, 2013a). Specifically, a walkthrough by the prison governor and staff of the 3D model at the design stage so they could suggest changes to suit their needs led to a saving of $£ 800000$ (Schünmann, 2013). BIM is considered the key to driving other construction industry initiatives such as lean construction, sustainability and off-site manufacturing.

\section{Connection between off-site manufacturing and BIM}

BIM can facilitate off-site manufacturing in many different ways. BIM allows greater precision in specifying material requirements, which can reduce over-ordering and thus decrease construction site waste. Also, BIM can assist fabricators and contractors by providing a $3 \mathrm{D}$ model of element positions. BIM can also store building information to support maintenance of the building and eventual deconstruction and material reuse at the end of life. Proper use of BIM technologies can accurately represent geometry, behaviour and 
properties of individual building components/objects and can facilitate their incorporation into standardised building elements or volumes and made available digitally (Nawari, 2012). The wealth of information contained within or linked to BIM models allows the possibility for direct interfacing between designers, suppliers, manufacturers and users. Ezcan et al. (2013) argued that providing an improved design, facilitating collaboration and covering accurate and extensive amount of information seem to be the most useful benefits of BIM for bridging the off-site manufacturing implementation gaps, avoiding longer lead-in times, high costs and modification problems. If BIM is used in modelling off-site construction components, then designing and deploying off-site manufactured projects will be easier. In a nutshell, Eastman and Sacks (2008) characterise BIM as more revealing and being able to depict the connection with off-site manufacturing by allowing "construction data to be machine processable and components to be manufactured without human intervention". In the ensuing section, the different BIM systems that can support off-site manufacturing will be examined.

\section{Current BIM systems that can support off-site manufacturing}

Successful off-site manufacturing is based on effective information exchange between supply chains (Alvarez-Anton et al., 2016). This requires efficient information management systems such as BIM. As argued in Hairstans (2010, pp. 34), "industrialised processes require accurate and reliable information". This section examines BIM systems that can facilitate the efficient management of off-site manufacturing information according to three BIM implementation aspects: a) Existing software, b) Data availability and c) Interoperability standards.

\subsection{Existing software}

BIM software packages are used in managing (i.e. modelling, analysis and sharing) project information, thereby fostering collaboration amongst project teams. Although it is not so straightforward to determine the number of BIM software types, buildingSmart has listed at least 150 BIM software packages currently being used in construction (http://www.buildingsmart-tech.org/). An extensive review of the different BIM software has been reported in Abanda and Tah (2014) and Abanda et al. (2015). The most common are BIM authoring software packages, e.g. Revit, Bentley, ArchiCAD; BIM project management/coordinating software, e.g. Bentley Projectwise and BIM energy analysis tool, e.g. Green Building Studio, EnergyPlus and Integrated Environmental Solutions. Modelling buildings in these software, can allow different project partners including clients to view and confirm or disapprove exact details and finishes virtually in the very early design stage. This aspect of virtual visualisation and decision-making facilitates off-site manufacturing, where repetition of components and processes are common (Vernikos, 2012). When a component and/or process has been virtually evaluated and found to be good, then it is simply repeated in factory conditions.

\subsection{Data availability}

A great advantage of BIM is that data in the form of objects can be modelled and re-used in the design of buildings or in other applications. BIM objects for buildings are akin to Lego blocks for houses, where children use their initiative to assemble a house from Lego blocks. While in the case of Lego blocks, they are poured from a bag and assembled manually to form a house, BIM software are used in picking the different BIM objects from BIM object libraries for designing a house. These objects are generally stored in a library or repository 
within BIM software installation folders or contained externally in some other organisation's storage systems. As an example of an installation-based repository, when Revit is installed a family of objects is also installed in one of its folders. These objects can be used at any time and can be re-modified before use in different applications. On the other hand, other external repositories could be cloud-based open source. The most common types of BIM libraries are examined in Table 1. 
Table 1: Examples of BIM object libraries

\begin{tabular}{|c|c|c|c|}
\hline Name & Description & Website/Source & \\
\hline BIMObject & $\begin{array}{l}\text { This is an online system that contains building objects. The system can be accessed via the website, web browser or } \\
\text { directly within Revit. It was formerly called Autodesk Seek }\end{array}$ & https://bimobject.com/ & IFC, .RVT, .DWG, ARCHICA \\
\hline SmartBIM & $\begin{array}{l}\text { This is an online system that contains building objects. The system can be accessed via the website, web browser or } \\
\text { directly within Revit }\end{array}$ & http://vimtrek.com/smartbim & Revit \\
\hline Revit City & This is an online system that contains free Revit families & http://www.revitcity.com/index.php & Revit \\
\hline $\begin{array}{l}\text { Trimble 3D } \\
\text { Warehouse }\end{array}$ & $\begin{array}{l}\text { (formerly called Google Warehouse) is an accompanying website for SketchUp where modellers can upload, download } \\
\text { and share three-dimensional models }\end{array}$ & https://3dwarehouse.sketchup.com/?hl=en & SketchUp \\
\hline $\begin{array}{l}\text { AirBus BIM Library } \\
\text { (or BIM Stop) }\end{array}$ & $\begin{array}{l}\text { This is one of the largest online building product library containing read and edited by common BIM software packages } \\
\text { such as Revit, ArchiCAD, Bentley, Vectorworks, including any Industry Foundation Classes (IFC) compliant software } \\
\text { packages and viewers }\end{array}$ & http://www.modlar.com/ & SketchUp, Revit, Archicad \\
\hline $\begin{array}{l}\text { UK Ministry of } \\
\text { Justice BIM library }\end{array}$ & This library contains laundry rooms, gates and grills, cell doors, pairs of cell rooms & HMYOI (2013) & IFC, Revit \\
\hline NBS Library & $\begin{array}{l}\text { This is the primary source of free-to-use BIM content in the UK. It contains thousands of generic and proprietary BIM } \\
\text { objects authored to the trusted NBS standard. The BIM objects can be accessed from the website or through a plugin in } \\
\text { Revit. }\end{array}$ & $\underline{\text { http://www.nationalbimlibrary.com/ }}$ & IFC, Revit \\
\hline ARCAT & This is a library of free BIM objects, families, and system files & http://www.arcat.com/bim/bim_objects.shtml & Revit (RVT, RFA), dwg files \\
\hline Familit & $\begin{array}{l}\text { These are family files that can either be loaded using Revit family manager into a project or saved externally. Families } \\
\text { can be downloaded or uploaded on both - free \& commercial basis. }\end{array}$ & http://www.familit.com/index.php?dir=RFA-2010 & RFA \\
\hline Sweets Network & $\begin{array}{l}\text { a growing library of high-quality models of proprietary building products from leading manufacturers for use in projects } \\
\text { developed using Building Information Modeling (BIM) software }\end{array}$ & $\begin{array}{l}\text { http://sweets.construction.com/QuickLinks/building- } \\
\text { information-modeling-bim }\end{array}$ & RFA, TXT \\
\hline BIMComponents.com & $\begin{array}{l}\text { The BIM Component database allows you to create, search, upload, and download custom BIM components of your } \\
\text { choice. }\end{array}$ & https://bimcomponents.com/ & Archicad \\
\hline Object Depository & It contains free Archicad file-based objects & $\begin{array}{l}\text { http://archicad- } \\
\text { talk.graphisoft.com/object_depository.php }\end{array}$ & Archicad \\
\hline Archibase.net & $\begin{array}{l}\text { Thousands of free objects in GDL format neatly categorized. Most of them seem to come from 3DS, so some of them } \\
\text { are very polygon-heavy }\end{array}$ & http://archibase.co/ & GDL format \\
\hline ARCHICADo & This contains 2D and 3D objects, mostly furniture and people & http://archicado.free.fr/ & $3 \mathrm{ds}$ \\
\hline 4DLibrary & Comprehensive commercial library for the Australian market, including doors, windows, stairs and more & http://4dlibrary.com.au/library/ & Archicad files \\
\hline ArchiRadar & Large collection of specific objects & http://www.archiradar.it/en/ & Archidad, SketchUP files \\
\hline ARCHICADObjects & This library contains details of construction objects including furniture & http://www.archicadobjects.com/page/index.html & Archicad files \\
\hline opengdl.org & This library contains buildings components and furniture for building use & http://opengdl.org/Default.aspx?tabid=987 & Archidad files \\
\hline Archisolutions & This library contains buildings components & http://www.archisolutions.com/index.html & Archidad files \\
\hline$\underline{\text { Skoldinov }}$ & This library contains building models and components & $\begin{array}{l}\text { http://www.skoldinov.spb.ru/index.php?lang=en\&lang2 } \\
=\mathrm{ru}\end{array}$ & Gsm files \\
\hline$\underline{\text { Rakennustieto }}$ & This library contains mostly furniture & http://www.rakennustieto.fi/kirjastot & GDL and dwg files \\
\hline
\end{tabular}




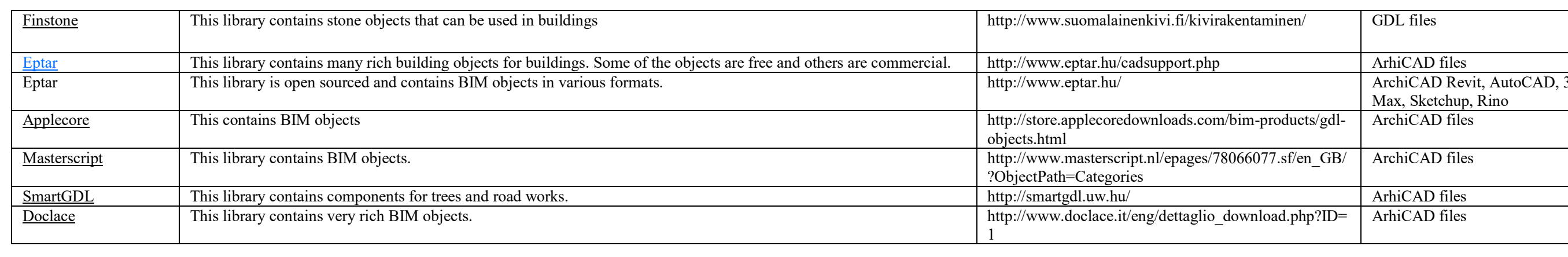


Based on Table 1, most of the libraries are open source online systems except the UK Ministry of Justice (MoJ) library that is not yet online and not clear whether it is free or not. Furthermore, some of the free libraries require registration by end-users while others require payment for specialised components. On exploring the libraries, the following key issues can be noted:

- most organisations define a protocol that manufacturers design their product to comply with before being uploaded to their repositories. Some libraries generally contain generic BIM objects from different countries (e.g. BIMObject) while others tend to be country specific (e.g. NBS for the UK)

- there is a lack of standardisation of data structures and content for BIM libraries

- most object files are in their native file formats (ArhiCAD, GDL, AutoCAD, Revit), with some in recommended exchange formats such as IFC. For the objects to be used in building modelling these have to be in file formats that can easily be processed by most common BIM software

- most of the libraries contain mostly components rather than whole pods or volumetric units. In relation to the types of off-site manufacturing, most of the components can be used in panelised and sub-assembly systems

- the products contain geometric properties as a minimum. However, there is a possibility of editing the properties and expanding the list to include other required properties

- other than the MoJ, it is not clear to what extent major construction companies and clients have developed BIM libraries that contain building components. This is not surprising as major companies are now able to see the benefits of BIM (Koch and Firmenich, 2011) and perhaps partly because of competitive advantage, do not want to share too many details with their competitors (Palos et al., 2013).

\subsection{Interoperability standards}

The ultimate success in modelling building components or objects for libraries depends on the ability to elicit all relevant data in the object (s) and the ease with which the data-rich object(s) can seemingly be exchanged between different project actors. Since the late 1990's, the completeness of building design libraries have been investigated (Owolabi et al., 2003). Based on this study, three factors required for free flow of information were identified. These are: a) an information exchange format, b) a specification exchange and c) a standard for the content of information to be incorporated in objects. The importance of free flow of information is a key principle of the UK National Building Specification (NBS). It establishes minimum requirements for BIM objects and lays down the foundations for robust and consistent information to be shared across different platforms. The NBS has published a standard that defines what constitute a high quality BIM object and provides consistency in the content and structure of these objects (NBS, 2014). The standard defines the information, geometry, behaviour and presentation of BIM objects to enable consistency, efficiency and interoperability across the construction industry.

At least four types of interoperability exist in the literature. These include syntactic, technical, semantic and organisation interoperability (Rezaei et al., 2014a; b; Bahar et al., 2013; Charalabidis et al., 2008a; b). For relevance and scope of this study, syntactic interoperability will be adopted. It refers to the ability of two (or more) separate systems or software 
programmes to communicate and exchange data (or information) with each other and use the data (or information) that has been exchanged (Rezaei et al., 2014a, b; Bahar et al., 2013). The exchange between systems depends on the data file formats that facilitate import or export into and from other computer systems. The concept of interoperability is quite important in off-site manufacturing if building components with associated properties or data are to be imported into or exported from different systems to be used for the design or development of off-site manufactured projects. In general, different file formats common in BIM can be categorised into three. The first file types are native file formats usually restricted to a particular type of software. For example, a building modelled in Revit will by default assume to be ".rvt", i.e. native Revit file extension. The implication of keeping files in this format means only Revit software can read these types of files. If any other software packages are to read Revit files, they must have been specially designed to do so. The second category is file formats that facilitate exchange of models between similar authoring software. The most popular for geometric data exchange is the IFC. The third category is file formats that are aimed for use in specialised applications (e.g. gbXML and COBie). The Green Building XML schema (gbXML) is the most popular file format used for building energy analysis. The Construction Operations Building Information Exchange (COBie) is a non-proprietary data format often used in facilities management. The National Building Specification requires a minimum of IFC and COBie data to be captured in BIM objects (NBS, 2014). This should be in addition to the other information such as the supplier's or developer's information.

\section{Drivers and constraints for the uptake of off-site manufacturing and BIM}

\subsection{Qualitative benefits and barriers of off-site manufacturing using BIM}

The vision set by the UK government, e.g. the time and cost targets in Construction Strategy 2025 are very stringent. It will be difficult to achieve them without improving both BIM and off-site manufacturing implementation together. A capable workforce with appropriate skills will deliver the much needed transformational change in the construction industry including the implementation of BIM and off-site manufacturing. Off-site manufacturing amongst others (e.g. lean construction, sustainable construction practices), provides greater benefits to achieve these targets. The benefits of off-site manufacturing have been widely reported in literature (Eastman and Sacks, 2008; Vernikos et al., 2014; Gibb, 2001; Blismas et al., 2006; Blismas and Wakefield, 2009; Gorgolewski, 2004). Despite these benefits, many barriers still exist hindering the uptake of BIM (Blismas and Wakefield, 2009; Pan and Goodier, 2012; Elnaas, 2014; Nadim and Goulding 2011). BIM can be used to enhance existing benefits of off-site manufacturing and can significantly contribute in removing most barriers hindering the uptake of BIM. While most studies generally report positive impacts of BIM on traditional construction, it can be argued that the impacts on off-site manufacturing can even be greater given off-site manufacturing already has so many benefits over traditional construction methods. That notwithstanding, there are already some few studies discussing the impacts of BIM on off-site manufacturing (e.g. Vernikos et al., 2014; Nawari, 2012; Jayasena et al., 2016; Lee and Kim, 2017). Thus it is important to view BIM as an emerging paradigm that can be used to enhance existing benefits and overcome existing challenges of off-site manufacturing. This is examined in Table 2. 
Table 2: Enhancing benefits and barriers of off-site manufacturing using BIM: A qualitative perspective

\begin{tabular}{|c|c|c|c|}
\hline Parameters & Drivers and advantages of off-site manufacturing & Barriers and constraints & How BIM can enhance the benefits and also improve the barriers \\
\hline Quality & $\begin{array}{l}\text { Product (building components) tried and tested in factory. } \\
\text { Greater consistency, as same product types are exactly } \\
\text { identical; more control of quality especially with regards to } \\
\text { compliance with standards (Pan and Goodier,2012; Blismas } \\
\text { et al., 2006; Blismas, 2007; Elnaas et al 2014) }\end{array}$ & $\begin{array}{l}\text { The image of off-site manufacturing is } \\
\text { coloured by the experiences of the past, } \\
\text { especially around 1960s where some } \\
\text { prefabricated buildings collapsed (Waskett, } \\
\text { 2001). }\end{array}$ & $\begin{array}{l}\text { Quality of data in BIM is improved and highly accurate leading to improved quality of } \\
\text { building components (Wong and Fan, 2013; Suermann and Issa, 2009; Stanley and Thurnell, } \\
\text { 2014). Building or components can be virtually built and tested in the factory before erecting } \\
\text { on site (Shade et al., 2011). This minimises errors that could possibly jeopardise quality. }\end{array}$ \\
\hline Cost/value & $\begin{array}{l}\text { Lower preliminary costs, Increase certainty-less risk, } \\
\text { Increased in added value, Lower overheads, Less on-site } \\
\text { damage and Less waste (Blismas et al. 2006; Elnaas et al. } \\
\text { 2014; Serial productions leads to significant reduction in } \\
\text { formwork and hence cost (Alvarez-Anton et al., 2016); } \\
\text { Offer good economic value (Boyd et al., 2013). }\end{array}$ & $\begin{array}{l}\text { Perceived as expensive when compared to } \\
\text { traditional methods. High initial and set-up } \\
\text { costs (Blismas, 2007). Cranage costs can be } \\
\text { very high (Blismas, 2007). Intercity or } \\
\text { county transport can be very high and can } \\
\text { negate any advantage (Blismas, 2007) }\end{array}$ & $\begin{array}{l}\text { Clashes detected virtually leads to significant cost savings (Azhar, 2011; Bryde et al., 2013). } \\
\text { Collaborative viewing of models leading to improved communications and trust between } \\
\text { stakeholders and enabled rapid decision making early in the process leads to cost savings } \\
\text { (Azhar, 2011). Efficient nD scheduling leads to projects to be delivered in time and budget } \\
\text { (Azhar, 2011). Pre-design investigation that prevents costly and time-consuming redesign at } \\
\text { later stages (Azhar, 2011). }\end{array}$ \\
\hline Time & $\begin{array}{l}\text { Less time spent on site, Speed of delivery of product, Less } \\
\text { time spent on commission, Guaranteed delivery- more } \\
\text { certainty over the programme and reduced management } \\
\text { time (Blismas et al. 2006; Boyd et al., 2013) }\end{array}$ & & $\begin{array}{l}\text { BIM provides opportunities to gain time in delivering construction projects. Using } \\
\text { coordination resolution in pre-construction requests for information (RFIs) and change } \\
\text { orders can be reduced to zero (Bryde et al., 2013). By exploring nD models using BIM can } \\
\text { lead to the identification and avoidance of errors that should have occurred during the } \\
\text { execution of real project (Azhar, 2011; Bryde et al., 2013). }\end{array}$ \\
\hline Productivity & $\begin{array}{l}\text { Less nagging, Less site disruption, reduction in the use of } \\
\text { wet trades, removal of difficult operations from on-site, } \\
\text { Work being undertaken at the same time both on-site and } \\
\text { off-site (Blismas et al. 2006) }\end{array}$ & & $\begin{array}{l}\text { Using coordination resolution in pre-construction, RFIs and change orders can be reduced to } \\
\text { zero (Bryde et al., 2013; Stanley and Thurnell, 2014). }\end{array}$ \\
\hline $\begin{array}{l}\text { People and } \\
\text { Occupational } \\
\text { safety and } \\
\text { health } \\
\text { (OHS) }\end{array}$ & $\begin{array}{l}\text { Fewer people on-site hence reduced number of on-site } \\
\text { accidents. Off-site manufacturing is independent of local } \\
\text { labour issues which can at times be political (Blismas et al. } \\
\text { 2006). }\end{array}$ & $\begin{array}{l}\text { The need for cranes for transporting building } \\
\text { components or whole buildings has safety } \\
\text { issues associated with their use (Blismas, } \\
\text { 2007) }\end{array}$ & $\begin{array}{l}\text { By modelling virtually and integrating with Geographical Information Systems, safety can } \\
\text { be improved by anticipating problems on site earlier in the planning stage (Irizarry et al., } \\
\text { 2013; El Meouche et al., 2013). Also, automated safety checking platforms developed in } \\
\text { BIM systems inform construction engineers and managers by reporting, why, where, when, } \\
\text { and what safety measures are needed for preventing fall-related accidents before } \\
\text { construction starts (Zhang et al., 2013). }\end{array}$ \\
\hline Process & $\begin{array}{l}\text { Simplified construction process. Systems can easily be } \\
\text { measured and more accurately. Leads to quicker completion } \\
\text { which in turn reduces site disruptions and hazards (e.g. } \\
\text { decreased road closures) (Blismas et al. 2006). }\end{array}$ & $\begin{array}{l}\text { Require more pre-planning on a project } \\
\text { which can potentially increase lead times } \\
\text { and may nullify any overall time advantages. } \\
\text { Generally very low level of IT integration in } \\
\text { the construction industry. Not flexible, does } \\
\text { not allow changes as too expensive once } \\
\text { manufactured (Blimas, 2007). }\end{array}$ & $\begin{array}{l}\text { The ultimate aim of BIM is to improve the construction process. There are many } \\
\text { perspectives to this. By designing in 3D BIM many other tasks are easily automated, e.g. } \\
\text { generating sections and views from a plan. The model also enables new and existing assets } \\
\text { to be integrated seamlessly. Through collaboration, all project partners - different design } \\
\text { disciplines, the customer, contractor, specialists and suppliers - use a single, shared 3D } \\
\text { model, cultivating collaborative working relationships. This ensures everyone is focused on } \\
\text { achieving best value, from project inception to eventual decommissioning. During the } \\
\text { execution of the project, on-site activities can easily be managed and more effectively. } \\
\text { These, amongst others are activities that improve the construction process. }\end{array}$ \\
\hline $\begin{array}{l}\text { Logistics and } \\
\text { site operations }\end{array}$ & $\begin{array}{l}\text { Fewer trades on-site leading to better coordination. In } \\
\text { remote areas where there is scarcity of trades, off-site } \\
\text { manufacturing components can be transported from factory } \\
\text { to site where the components are assembled (Blismas, } \\
\text { 2007). Off-site manufacturing implies a reduction in site } \\
\text { disruptions, excessive subcontracting and spatial } \\
\text { requirements (Arashpour et al., 2015) }\end{array}$ & $\begin{array}{l}\text { Production facility logistics and stock } \\
\text { management difficult (e.g. limited access on- } \\
\text { site for manoeuvre, restricted access to site } \\
\text { for delivery, size of components) }\end{array}$ & $\begin{array}{l}\text { BIM provides opportunities to coordinate supply and site activities by integrating their } \\
\text { decisions and recognizing existing interdependencies to minimize the total material } \\
\text { management cost (Deshpande and Whitman, 2014; Said and El-Rayes, 2014). }\end{array}$ \\
\hline $\begin{array}{l}\text { Lack of } \\
\text { knowledge }\end{array}$ & & $\begin{array}{l}\text { Most professionals have not embarked on } \\
\text { off-site manufacturing because of lack of }\end{array}$ & \\
\hline
\end{tabular}




\begin{tabular}{|c|c|c|c|}
\hline & & $\begin{array}{l}\text { knowledge about the benefits of off-site } \\
\text { manufacturing (Waskett, 2001). }\end{array}$ & \\
\hline $\begin{array}{l}\text { Industry market } \\
\text { culture }\end{array}$ & & $\begin{array}{l}\text { A very conservative industry. Professionals } \\
\text { very resistant to change. }\end{array}$ & \\
\hline $\begin{array}{l}\text { Social } \\
\text { sustainability }\end{array}$ & & & Improves communication and collaboration amongst project partners (Wong and Fan, 2013) \\
\hline $\begin{array}{l}\text { Economic } \\
\text { sustainability }\end{array}$ & & & $\begin{array}{l}\text { Improves collaboration and communication as well as early anticipation of problems reduces } \\
\text { undesirable waste due to improved construction management and hence reduces project cost } \\
\text { (Wong and Fan, 2013) }\end{array}$ \\
\hline $\begin{array}{l}\text { Environmental } \\
\text { sustainability }\end{array}$ & $\begin{array}{l}\text { Better management of site activities leading to reduction in } \\
\text { waste (Chen et al., 2010; Blismas, 2007; Elnaas et al., 2014; } \\
\text { Yunus and Yang, 2012; 2014). Cleaner sites due to reduced } \\
\text { number of on-site wet trades (Blismas, 2007). }\end{array}$ & & $\begin{array}{l}\text { Modelling building virtually allows for potential mistakes to be identified before erecting the } \\
\text { real buildings. This minimises waste that would have occurred as a result of a mistake (s). } \\
\text { The quality of design and construction of projects can also improve better living } \\
\text { environment (Wong and Fan, 2013). BIM can also be integrated with most environmental } \\
\text { standards (e.g. BEAM Plus, BREEAM and LEEDS) for use in determining environmental } \\
\text { compliance (Wong and Kuan, 2014; Kasim et al. 2012; Azhar et al., 2011; Zanni et al. 2014) } \\
\text { Quick materials and quantities take-off allows easier calculation of environmental impact } \\
\text { (Patlakas et al., 2015a). }\end{array}$ \\
\hline Profit margin & & & $\begin{array}{l}\text { If project managers and quantity surveyors understand } \mathrm{nD} \text { modelling, they can better exploit } \\
\text { BIM tools to stay within schedules and minimise waste. This can lead to increased profit } \\
\text { margins. }\end{array}$ \\
\hline $\begin{array}{l}\text { Paper based } \\
\text { design }\end{array}$ & & $\begin{array}{l}\text { Use of paper-based drawings inhibits off-site } \\
\text { manufacturing (Vernikos et al., 2014). }\end{array}$ & $\begin{array}{l}\text { BIM significantly improves upon paper-based drawings through its digital representation of } \\
\text { buildings with rich data. A community cased study project in Libreville, Gabon revealed } \\
\text { that BIM-based modelling significantly decreases modelling time and increases model } \\
\text { quality (Gibson, 2012). By integrating a BIM-deconstructability assessment score in a BIM } \\
\text { software, automatic capture of design parameters can be improved leading to a reduction of } \\
\text { errors that could have been caused by manual editing of design parameters (Akinade et al., } \\
\text { 2015). }\end{array}$ \\
\hline $\begin{array}{l}\text { Lack of } \\
\text { available codes } \\
\text { and standards }\end{array}$ & & $\begin{array}{l}\text { Amongst } 21 \text { barriers to the uptake of off-site } \\
\text { production, lack of codes and standards } \\
\text { topped the list (Zhai et al., 2014). }\end{array}$ & $\begin{array}{l}\text { Some studies (e.g. Ciribin et al., 2016; Tan et al., 2010) have demonstrated the use of BIM } \\
\text { for compliance and code checking. Should off-site manufacture adopt standards and codes, } \\
\text { then BIM can be used to enhanced verification and compliance. }\end{array}$ \\
\hline $\begin{array}{l}\text { Poor } \\
\text { integration in } \\
\text { the supply } \\
\text { chain }\end{array}$ & & $\begin{array}{l}\text { Amongst } 21 \text { barriers to the uptake of off-site } \\
\text { production, poor integration in the supply } \\
\text { chain was second on the list (Zhai et al., } \\
\text { 2014) }\end{array}$ & $\begin{array}{l}\text { BIM can be used to integrate supply chain which improves performance (Papadonikolaki et } \\
\text { al., 2016). }\end{array}$ \\
\hline
\end{tabular}




\subsection{Some quantitative impacts of BIM on traditional construction and off-site manufacturing methods}

While many studies (see Table 2) tend to report the benefits and constraints of BIM on traditional and/or off-site manufacturing, most of the benefits are not measured and thus, arguably are assertions. Expressions such as "BIM improves design reliability", "BIM reduces design risk", "BIM reduces waste", "BIM enhances coordination and minimises design errors", "BIM reduces cost associated with planning", and so on, are very common in peer-reviewed literature. However, there is hardly a mention of how much is the gain. This is partly due to the challenges or lack of a common method of quantifying BIM benefits (buildingSmart UK, 2010). Quantitative benefits constitute grounded evidence that can convince prospective end-users including even laggards to adopt BIM and off-site manufacture. The quantitative benefits off-site manufacturing over traditional construction, BIM for traditional construction and BIM for off-site manufacturing will be examined in Table 3. It is important to note that some related studies (e.g., Malekitabar et al., 2016; Chan et al., 2016; Li et al., 2014; Azhar, 2011; Lu et al., 2014; Delcambre, 2014) failed to explicitly state the type of construction. Hence, it was difficult to confirm whether quantitative benefits of BIM pertained to traditional construction or off-site manufacturing. In cases of doubts or lack of clarity about the construction types used, the quantitative benefit(s) have been inserted in a merged cell under the traditional construction and off-site manufacturing benefits' of BIM in Table 3. 


\section{Table 3: Quantitative benefits of off-site manufacturing and BIM}

\begin{tabular}{|c|c|c|c|}
\hline Parameters & Benefits of off-site manufacturing over traditional construction & $\begin{array}{l}\text { Benefits of BIM for } \\
\text { traditional construction }\end{array}$ & Benefits of BIM for off-site manufacturing \\
\hline \multirow[t]{2}{*}{ Safety } & $\begin{array}{l}\text { When modular construction is used, on-site reportable accidents can be reduced by } \\
80 \% \text { compared to onsite construction (Lawson et al., 2012). Studies by Cao et al. } \\
\text { (2016) revealed that } 6.61 \% \text { reduction in health damage for a sample prefabricated } \\
\text { house in China compared to a traditionally constructed house. }\end{array}$ & & $\begin{array}{l}\text { The implementation of BIM/virtual design and construction systems on the } \\
\text { coordination of Mechanical, Electrical and Plumbing (MEP) systems in a } \$ 96.6 \\
\text { million healthcare project in Northern California of } 100 \% \text { pre-fabrication only } \\
\text { one recorded injury throughout the installation of MEP systems over a } 250000 \\
\text { square feet project area (Khanzode et al., 2008). }\end{array}$ \\
\hline & & \multicolumn{2}{|c|}{$\begin{array}{l}\text { Using BIM } 40 \% \text { of potential fatalities in construction projects can be identified (Malekitabar et al., 2016). } \\
\text { Using BIM at design can prevent } 71 \% \text { of safety incidents (Gibb et al., } 2004 \text { and Zhou et al., } 2011 \text { cited in } \\
\text { Chan et al., (2016)). In Finland BIM adoption in housing projects have led to on-site accident reduction of } \\
5 \% \text { (Delcambre, 2014). }\end{array}$} \\
\hline Waste & $\begin{array}{l}84.7 \% \text { of construction waste can be avoided by adopting pre-fabrication (Akinade et } \\
\text { al., 2016). The use of precast construction can result in } 52 \% \text { in construction, } \\
\text { demolition and excavation waste (Jaillon et al., 2009). Reduction of site waste by } \\
70 \% \text { (Rogan et al., 2000). Prefabrication uses } 35 \% \text { less concrete, } 25 \% \text { less } \\
\text { reinforcement, } 40 \% \text { less wastage of tile than in traditional construction (Tam et al., } \\
\text { 2015). Prefabrication uses about } 30 \% \text { less site man-power (in man-day) than in } \\
\text { traditional construction (Tam et al., 2015). }\end{array}$ & \multicolumn{2}{|c|}{$\begin{array}{l}\text { A BIM-based design validation can prevent between 4.3-15.2\% of construction waste that might have been } \\
\text { generated without the use of BIM (Won et al., 2016). In Finland BIM adoption in housing projects has led to } \\
\text { a waste reduction of } 45 \% \text { (Delcambre, 2014). }\end{array}$} \\
\hline $\begin{array}{l}\text { Return on } \\
\text { investment } \\
\text { (ROI) }\end{array}$ & & \multicolumn{2}{|c|}{$\begin{array}{l}\text { The return on investment (ROI) is } 735 \% \text { for an apartment block project of } 57 \text { units in Stockholm gained by } \\
\text { the use of Virtual Design and Construction (VDC)/BIM in the project (Sen, 2012). Using } 3 \text { case studies, the } \\
\text { ROI varied from } 16 \% \text { to } 1654 \% \text { out of } 4 \text { projects (Giel and Issa, 2013). Azhar (2011) reported an average } \\
\text { ROI on a number of projects executed using BIM of } 1663 \% \text { with a minimum of } 140 \% \text { and maximum of } 39 \\
900 \% \text {. }\end{array}$} \\
\hline \multirow[t]{2}{*}{$\begin{array}{l}\text { Request for } \\
\text { information } \\
\text { (RFI) }\end{array}$} & & \multicolumn{2}{|c|}{$\begin{array}{l}\text { Due to the use of VDC/BIM, the total number of RFIs was reduced by } 34 \% \text { on a small tilt-wall project, } 68 \% \\
\text { on a three-story assisted living facility, and } 43 \% \text { on a midrise commercial condominium project (Giel and } \\
\text { Issa, 2013) }\end{array}$} \\
\hline & & & $\begin{array}{l}\text { The implementation of BIM/virtual design and } \\
\text { construction systems on the coordination of Mechanical, } \\
\text { Electrical and Plumbing (MEP) systems in a } \$ 96.6 \\
\text { million healthcare project in Northern California of } \\
100 \% \text { pre-fabrication produced only a handful of } \\
\text { requests for information for the coordination of the MEP } \\
\text { systems between contractors and the designers }\end{array}$ \\
\hline
\end{tabular}




\begin{tabular}{|c|c|c|c|}
\hline & & & (Khanzode et al., 2008). \\
\hline Design errors & & $\begin{array}{l}\text { A BIM-based design validation was conducted } \\
\text { on two residential buildings of total floor area of } \\
120000 \mathrm{~m}^{2} \text { led to the identification of } 381 \text { design } \\
\text { errors (Won et al., 2016). Similarly, the same } \\
\text { BIM-based validation technique applied to a } \\
\text { sport complex led to the identification of } 136 \\
\text { design errors (Won et al., 2016). BIM can be } \\
\text { used to automatically detect design-related errors } \\
\text { by issuing warnings for potential problems } \\
\text { related to model elements (Lee et al., 2015). } \\
\text { Based on warning data collected from three } \\
\text { California healthcare projects, the analysis } \\
\text { revealed that the } 15-80 \text { Pareto rule applies-15\% } \\
\text { of the warning messages are responsible for } \\
\text { nearly } 80 \% \text { of the warnings (Lee et al., 2015) }\end{array}$ & $\begin{array}{l}\text { The use of 4D Revit-based models can reduce mistakes } \\
\text { to a greater extent (twice as much) in construction } \\
\text { processes and help in detecting and removing them more } \\
\text { quickly (Reizgevičius et al., 2013). }\end{array}$ \\
\hline Re-work & & \multicolumn{2}{|c|}{$\begin{array}{l}\text { The implementation of BIM/virtual design and construction systems on the coordination of Mechanical, } \\
\text { Electrical and Plumbing (MEP) systems in a } \$ 96.6 \text { million healthcare project in Northern California of } 100 \% \\
\text { pre-fabrication only one recorded injury throughout the installation of MEP systems over a } 250000 \text { square } \\
\text { feet project area, } 0.2 \% \text { rework for the whole project for the mechanical subcontractor (Khanzode et al., 2008). }\end{array}$} \\
\hline Change orders & & \multicolumn{2}{|c|}{$\begin{array}{l}\text { Due to the use of VDC/BIM, the number of change orders reduced by } 40 \% \text { on a small tilt-wall project, } 48 \% \\
\text { on a three-story assisted living facility, and } 37 \% \text { on a midrise commercial condominium project (Giel and } \\
\text { Issa, 2013). }\end{array}$} \\
\hline \multirow[t]{2}{*}{ Time } & $\begin{array}{l}\text { The productive time can be improved by up to } 12 \% \text { (Tam et al., 2015). The time } \\
\text { required to complete a regular modular house was } 4 \text { months compared to } 14 \text { months } \\
\text { for a similarly traditional or conventional constructed house (Zenga and Javor, 2008) }\end{array}$ & \multicolumn{2}{|c|}{$\begin{array}{l}\text { The implementation of BIM/virtual design and construction systems on the } \\
\text { coordination of Mechanical, Electrical and Plumbing (MEP) systems in a } \$ 96.6 \\
\text { million healthcare project in Northern California, USA of } 100 \% \text { pre-fabrication } \\
\text { led to } 6 \text { months' savings on the schedule and about } \$ 9 \text { savings in cost for the } \\
\text { overall project (Khanzode et al., 2008). In an experimental study carried out } \\
\text { using Lego blocks by Reizgevičius et al. (2013), they argued that 4D Revit- } \\
\text { based models can shorten construction time by 1/3. Shen and Issa (2010) } \\
\text { demonstrated that the quantity estimation time of a simple cast-in-place concrete } \\
\text { wall using BIM-assisted systems is approximately } 20.67 \text { minutes compared to } \\
27.58 \text { minutes using manual estimating methods. This time increases with } \\
\text { increasing complexity of a building. }\end{array}$} \\
\hline & $\begin{array}{l}\text { Shorter build times, typically } 50-60 \% \text { less than traditional onsite construction (Rogan } \\
\text { et al., 2000). Faster construction times by up to } 50 \% \text { (Rogan et al. (2000). } \\
\text { Conventional fit-out time of } 95-105 \text { days from formwork stripping to completion can } \\
\text { be reduced to } 30 \text { days (Boyd et al., 2013). }\end{array}$ & \multicolumn{2}{|c|}{$\begin{array}{l}\text { The construction of an apartment block project of } 57 \text { units in Stockholm was completed } 20 \text { days earlier due } \\
\text { to the use of VDC/BIM (Sen, 2012) }\end{array}$} \\
\hline
\end{tabular}




\begin{tabular}{|c|c|c|}
\hline & & $\begin{array}{l}\text { A report that documented construction practices over several years, found that in } 2009 \text { the average duration } \\
\text { of BIM projects was } 27 \% \text { shorter than traditional projects. By 2012, BIM had widened the gap to } 37 \% \text {. This } \\
\text { suggests that the advantages of BIM become more pronounced as users gain experience and become more } \\
\text { proficient with the technology. One survey even estimates that BIM's data sharing ability alone is enough to } \\
\text { reduce the duration of a single project by up to } 7 \% \text { (Branz, undated) }\end{array}$ \\
\hline Space & & Space savings between $1.5 \%$ to $54 \%$ achieved in standard kitchen design (HM Government, 2013b) \\
\hline \multirow[t]{4}{*}{ Cost } & $\begin{array}{l}\text { A reduction of capital cost by up to } 10 \% \text { can be achieved through the use of off-site } \\
\text { manufacturing (Rogan et al., 2000). A reduction of onsite labour costs of up to } 50 \% \\
\text { can be achieved through the use of off-site manufacturing (Postnote, 2000). }\end{array}$ & $\begin{array}{l}\text { Average sized kitchen's capital cost reduced by approximately } 5 \% \text { (HM Government, 2013b). A saving of } \\
4 \% \text { of total construction cost on apartment block project of } 57 \text { units in Stockholm (Sen, 2012). A construction } \\
\text { cost saving of between } 8 \text { and } 10 \% \text { for Royal Opera House and Portcullis House (Gilkinson et. al., 2015). }\end{array}$ \\
\hline & & $\begin{array}{l}\text { In the UK, the MoJ adopted BIM in delivering the Cookham Wood project } \\
\text { (value of } £ 20 \text { million), that yielded a } 20 \% \text { cost saving (HMYOI, 2013). Also, } \\
\text { through data sharing and collaborative working including the use of BIM library, } \\
\text { a four storey office building consisting pre-constructed units near the main } \\
\text { terminal at Stansted achieved cost savings of } 9.8 \% \text { on project cost and } 18 \% \text { in } \\
\text { cost of drawing production (buildingSmart UK, 2010). Still in the UK, a project } \\
\text { extranet, used for information exchange, saved up to } 50 \% \text { of effort compared to } \\
\text { traditional methods on a } £ 30 \text { million retail development building project in } \\
\text { Enfield, UK (buildingSmart UK, 2010). The implementation of BIM/virtual } \\
\text { design and construction systems on the coordination of Mechanical, Electrical } \\
\text { and Plumbing (MEP) systems in a } \$ 96.6 \text { million healthcare project in Northern } \\
\text { California, USA of } 100 \% \text { pre-fabrication led to about } \$ 9 \mathrm{M} \text { savings in cost for } \\
\text { the overall project (Khanzode et al., 2008). }\end{array}$ \\
\hline & & $\begin{array}{l}\text { In a modular healthcare facility in Charlotte, North Carolina of value } \$ 44 \mathrm{Million} \\
\text { where BIM implementation cost totaled } \$ 44,000 \text { led to savings of } \$ 220,000 \text { (Lu } \\
\text { and Korman, 2010) }\end{array}$ \\
\hline & & $\begin{array}{l}\text { In Hong Kong, Lu et al. (2014) found that by implementing BIM in delivering a public housing project, a } \\
6.92 \% \text { cost-saving was achieved. The use of BIM in managing the Aquarium Hilton Garden Inn in Atlanta, } \\
\text { Georgia led to the overall cost benefit of over } \$ 200000 \text {, attributed to the elimination of clashes (Azhar, } \\
2011 \text { ). The use of BIM in the predesign stage of the Savanah State University in Savannah project in Georgia } \\
\text { led to the cost benefit was } \$ 1995000 \text { (Azhar, 2011). The use of BIM in managing the Mansion on Peachtree } \\
\text { project in Atlanta Georgia led to a cost benefit of } \$ 15000 \text {. }\end{array}$ \\
\hline Profit margins & & $\begin{array}{l}\text { In Finland BIM adoption in housing projects have led to the following benefits: increase profit margins of } \\
45 \% \text { (Delcambre, 2014). }\end{array}$ \\
\hline Labour saving & $\begin{array}{l}\text { Warszawski (1999) reported that the benefits of industrialised building include } \\
\text { savings in manual labour on site (up to } 40-50 \% \text { of the input in conventional }\end{array}$ & $\begin{array}{l}\text { Furthermore, the use of BIM for 4D simulation led to a project's direction to be shortened by } 3 \text { months. } \\
\text { Also, some quantitative benefits of some case study buildings have been reported in the US (Azhar, 2011). }\end{array}$ \\
\hline
\end{tabular}




\begin{tabular}{|c|c|c|c|}
\hline & $\begin{array}{l}\text { construction), especially in skilled trades such as formwork, masonry, plastering, } \\
\text { painting, carpentry, tiling, and pipe-laying (electrical and water supply). }\end{array}$ & \multicolumn{2}{|c|}{$\begin{array}{l}\text { The use of BIM in managing the Aquarium Hilton Garden Inn in Atlanta, Georgia led to the saving of } 1143 \\
\text { hours from scheduling in BIM. }\end{array}$} \\
\hline $\begin{array}{l}\text { Environmental } \\
\text { sustainability }\end{array}$ & $\begin{array}{l}\text { Semi-prefabricated method (precast facades, precast staircase, precast corridors) of a } \\
\text { rental housing project produces less greenhouse gas emissions per } \mathrm{m}^{2} \text { than a } \\
\text { residential project constructed using a conventional method. The former produced } \\
336 \mathrm{~kg} / \mathrm{m}^{2} \text { while the latter produced } 368 \mathrm{~kg} / \mathrm{m}^{2} \text { (Mao et al., 2013). Average greenhouse } \\
\text { gas emissions of modular buildings is estimated to be nearly 6tonnes of } \mathrm{CO}_{2 \text {-eq }} \text { less } \\
\text { than that of traditional buildings per } 186 \mathrm{~m}^{2} \text { home (Quale et al., 2012). Al-Hussein et } \\
\text { al. (2009) found that modular processes led to a } 43 \% \text { reduction in } \mathrm{CO}_{2} \text { emissions } \\
\text { compared to onsite processes. The energy consumption of a modular home is } 4.6 \% \\
\text { less than that of a conventional or traditional home (Kim, 2008). Studies by Cao et al. } \\
\text { (2016) revealed that a sample prefabricated residential building (PRB) construction } \\
\text { was more efficient, with a } 20.49 \% \text { reduction in total energy consumption, } 35.82 \% \\
\text { reduction in resource depletion, 3.47\% reduction in ecosystem damage compared to } \\
\text { the sample traditional residential building (TRB) construction. Studies by Ji et al. } \\
\text { (2016) revealed that } 6 \text { building materials (concrete, cement, sand, steel, glass and } \\
\text { brick) in precast in-situ construction method was found to generate about } 257.30 \text { tons } \\
\text { of embodied greenhouse gas (GHG) emissions per } 1000 \mathrm{~m}^{2}, \text { whereas the amount for } \\
\text { conventional construction method was about } 266.14 \text { tons per } 1000 \mathrm{~m}^{2}\end{array}$ & & \\
\hline $\begin{array}{l}\text { Number of } \\
\text { site workers }\end{array}$ & $50 \%$ less onsite work, thus requiring fewer trade-qualified (Postnote, 2003) & & \\
\hline $\begin{array}{l}\text { Number of } \\
\text { journey to } \\
\text { sites }\end{array}$ & & \multicolumn{2}{|c|}{$\begin{array}{l}\text { In Sweden, Skanska reported the use of iPad in sharing construction information reduced the number of } \\
\text { journeys to site by a half (Delcambre, 2014). }\end{array}$} \\
\hline $\begin{array}{l}\text { Clash } \\
\text { detection }\end{array}$ & & \multicolumn{2}{|c|}{$\begin{array}{l}\text { Li et al. (2014) demonstrated great potential in the use of BIM for MEP clash detection and } 4 \mathrm{D} \text { simulation. Ir } \\
\text { the project of gross floor area } 28124 \mathrm{~m}^{2} \text {, the use of BIM to manage clashes led to time saving of } 65.6 \text { days. }\end{array}$} \\
\hline & & & $\begin{array}{l}\text { By using the BIM model for a high school project, Gastonia, } \\
\text { North Carolina, US , } 258 \text { conflicts were identified and } \\
\text { eliminated during the design phase on a modular (Lu and } \\
\text { Korman, 2010). }\end{array}$ \\
\hline $\begin{array}{l}\text { External } \\
\text { scaffolding }\end{array}$ & $100 \%$ external scaffolding is needed (Tam et al., 2015) & $\begin{array}{l}\text { No external scaffolding is needed (Tam et } \\
\text { al., 2015) }\end{array}$ & \\
\hline
\end{tabular}




\section{Key Findings}

In this work four main findings, one each related to off-site manufacturing and BIM and two emerging from the synergy between off-site manufacturing and BIM were uncovered. The connections between the findings depicted in Figure 3.

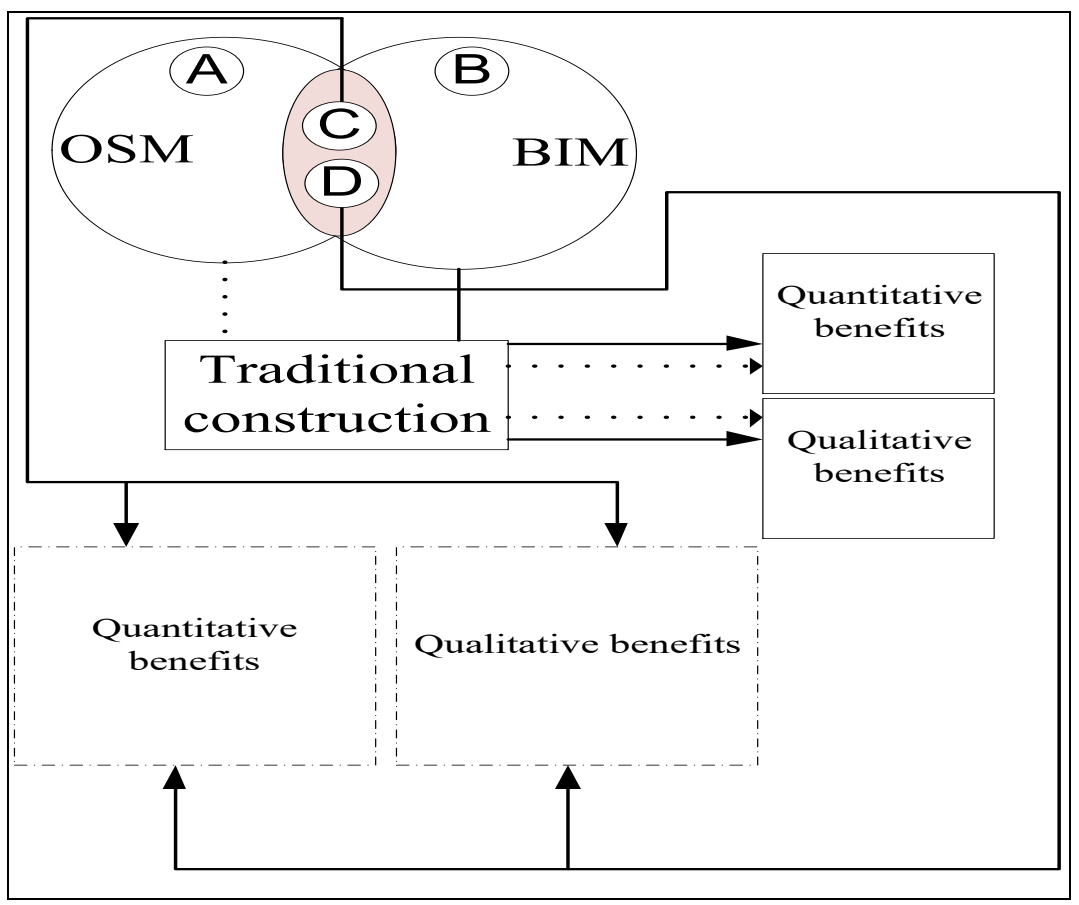

Figure 3: Relationships between study findings

Firstly, in addition to qualitative studies, this study identified quantitative benefits of off-site manufacturing over traditional construction. This is depicted as A in Figure 3 with details explained in the second columns of Tables $2 \& 3$.

Secondly, the study builds on the qualitative benefits of BIM on traditional construction, widely reported in the literature to expand on the quantitative benefits of BIM on the same, depicted as B in Figure 3, with details explained the third column of Table 3.

Thirdly, it emerged that despite the huge benefits inherent in off-site manufacturing, there are so many challenges hindering its uptake. These challenges have been discussed in the third column of Table 2. BIM leverages the benefits and provides opportunities to further overcome the challenges. Peer-reviewed literature that measure the impacts of BIM quantitatively in particular on off-site manufacturing are very sketchy. Demonstrating the quantitative benefits of BIM in delivering off-site manufacturing has a dual potential in driving the uptake of BIM and off-site manufacturing. This paper systematically collates the quantitative benefits of BIM on off-site manufacturing in the fourth column of Table 3. Furthermore, while the benefits of BIM for off-site manufacturing has been widely acknowledged in the literature, research about the technological potential of reaping the benefits are sketchy. The few studies that have discussed this technological potential of BIM for off-site manufacturing are Samarasinghe et al. (2015) and Sebastian et al. (2009). This study highlights the synergies between BIM and off-site manufacturing while detailing the technological potential of BIM for off-site manufacturing in section 7, captured as $\mathrm{C}$ in 
Figure 3. In section 7, the strength of BIM as a federated model that contains information is a natural system for fabrication processes and facilitates the construction of more complex components off-site than would have been with 2D Computer-Aided-Techniques or traditional manual design. The publication of interoperable BIM components in open source BIM libraries (see section 7.2) is quite important in the design of off-site manufactured buildings. This is because the interoperable BIM components underpin effective communication and information exchange between stakeholders involved in the delivery of off-site manufactured buildings.

Fourthly, in addition to the benefits of BIM implementation on off-site manufacturing, there are often low hanging fruits that are hardly discussed. In bad weather conditions, such as extreme cold temperatures in temperate regions or extreme hot conditions in tropical regions, onsite construction activities are impeded leading to longer execution time and hence budget overruns. In factory environments, the challenge associated with the weather is avoided in both the temperate and tropical regions. Using BIM in the off-site manufacturing in factory conditions is an added bonus, captured in D of Figure 3.

\section{Conclusions}

BIM is key in driving other innovative techniques currently being pushed by the government in improving the performance of the construction industry. Specifically, BIM is crucial in the use of off-site manufacturing techniques, lean construction and sustainability in construction. The strengths of BIM in containing data in interoperable formats and managing huge projects are great assets in fostering collaborative practices in the construction industry which translates to immense benefits to both traditional and off-site manufacturing of buildings. Whereas there is a plethora of literature espousing the benefits of BIM in traditional construction, there is a scarcity of literature reporting the benefits of BIM in off-site manufacturing. This is not surprising as off-site manufacturing has not been widely adopted despite the benefits that it offers.

The systematic appraisal of the literature undertaken indicates that despite the huge benefits inherent in off-site manufacturing, there are so many challenges hindering its uptake. The literature also indicates that BIM leverages these benefits and provides opportunities to further overcome the challenges. The impacts of BIM on traditional construction have been widely investigated although they are largely reported in very subjective qualitative rather than quantitative terms. These quantitative benefits have been systematically collated in this paper from the plethora of literature on the subject to aid understanding and appreciation. A serious attempt has been made to elicit and present the benefits of BIM in off-site manufacturing in quantitative terms despite the scarcity of literature in this aspect. It is hoped that future studies will make serious attempts in reporting the benefits in quantitative terms. This would have the dual potential of driving up the adoption of BIM and off-site manufacturing amongst construction stakeholders especially clients. Recent studies still support the fact that lack of knowledge about clear benefits of the former (e.g. Hosseini et al., 2016) and the latter (e.g. Mao et al., 2016) is still a huge barrier towards their uptake.

It has been challenging to identify the benefits in quantitative terms from the small number of reported studies due to a number of shortcomings. Most of the studies on the quantitative benefits of BIM were not holistic and seldom considered the whole project life cycle of offsite construction projects. Some studies failed to specifically state the type of construction. 
Hence, it was difficult to confirm whether the reported quantitative benefits of BIM were for traditional construction or off-site manufacturing. Most studies do not reveal the level of prefabrication or number of components that have been manufactured off-site. Furthermore, the methodologies used in determining the quantitative benefits are hardly discussed. The lack of methodological clarity, auditing, validation and comparing results cannot be easily conducted. From a methodological perspective, the desk-top method cannot provide clarify issues raised in the preceding sentences. Hence, there is need to be cautious in the use of such findings and a straightforward comparison between the different benefit values cannot be easily made.

Apart from a few exceptions, most literature tends to discuss only positive benefits of off-site manufacturing and/or BIM. We note some exceptions in Postnote (2003) and Hairstans (2010). Postnote (2003) argued that construction of a prefabricated housing can result to a cost increase of between $7-10 \%$. Volumetric off-site manufactured units need to consider the stability of 3 dimensional units before being transported which often leads to over design (Hairstans, 2010).

The aforementioned limitations are important aspects that should be considered in future studies and should be researched using more advanced research methods other than a literature review.

\section{References}

Abanda F.H. (2011) Knowledge modelling of emerging technologies for sustainable building development. A thesis submitted to the Faculty of Technology, Design and Environment in partial fulfilment of the requirements for the degree of Doctor of Philosophy. Oxford Brookes University, England, UK.

Abanda F.H. and Byers L. (2016) An investigation of the impact of building orientation on energy consumption in a domestic building using emerging BIM (Building Information Modelling). Journal of Energy, Vol. 97, pp. 517-527.

Abanda F.H. and Cabeza L.F. (2015) Investigating occupants' behaviour using emerging Building Information Modelling. In the proceedings of the ICSC15 - The CSCE International Construction Specialty Conference, Vancouver, Canada, June 7 - 10, 2015.

Abanda H. and Tah J.H. M. (2014) Free and open source Building Information Modelling for developing countries. ICT for Africa 2014 Conference, October 1-4, 2014 Yaoundé, Cameroon.

Abanda F.H., Vidalakis C., Oti A.H. and Tah J.H.M. (2015) A critical analysis of Building Information Modelling systems used in construction projects. Advances in Engineering Software, Vol. 90, pp. 183-201.

Akinade O.O., Oyedele L.O., Bilal M., Ajayi S.O. Owolabi H.A., Alaka H.A. and Bello S.A. (2015) Waste minimisation through deconstruction: A BIM based deconstructionability assessment score (BIM-DAS). Resources, Conservation and Recycling, Vol. 105, pp. 167176.

AIA (undated) Preparing for Building Information Modeling. [Online]American Institute of Architects. http://www.aia.org/practicing/groups/kc/AIAS077631 [1/1/2015].

Alaghbari W., Kadir M.R.A., Salim A. and Ernawati (2007) The significant factors causing delay of building construction projects in Malaysia. Journal of Engineering, Construction and Architectural Management, Vol. 14 (2), pp.192 - 206.

Al-Hussein M., Manrique J.D., and Mah D. (2009) North Ridge $\mathrm{CO}_{2}$ analysis report: comparison between modular and onsite construction. Report, University of Alberta, 
Alberta. [Online]

http://www.modular.org/IMAGES/foundation/NorthRidgeCO2Report.pdf [04/09/2016].

Alvarez-Anton L., Koob M., Diaz J. and Minnert J. (2016) Optimization of a hybrid tower for onshore wind turbines by Building Information Modeling and prefabrication techniques. Visualization in Engineering, Vol. 3. Doi:10.1186/s40327-015-0032-4.

Arayici Y., Ebgu C. and Coates P. (2012). Building information modelling (BIM) implementation and remote construction projects: Issues, challenges and critiques. ITcon, Special Issue Management of remote construction sites and the role of IT Systems, Vol. 17, pp. 75-92.

Arashpour M., Wakefield R., Blismas N. and Minas J. (2015) Optimization of process integration and multi-skilled resource utilization in off-site construction. Automation in Construction, Vol. 50, pp. 72-80.

Arif M. and Egbu C. (2010) Making a case for offsite construction in China. Engineering, Construction and Architectural Management, Vol. 17 (6), pp. 536-548.

Azhar S., Carlton W.A., Olsen D., and Ahmad I. (2011) Building information modeling for sustainable design and LEED ${ }^{\circledR}$ rating analysis. Automation in Construction, Vol. 20(2), pp. 217-224.

Azhar S. (2011) Building Information Modelling (BIM): benefits, risk and challenges for the AEC industry. Leadership Management Engineering, Vol. 11(3), pp. 241-252.

Babič Č., Podbreznik P. and Rebolj. (2010) Integrating resource production and construction using BIM. Automation in Construction, Vol. 19, pp. 539-543.

Bahar Y.N., Pere C., Landrieu J. and Nicolle C. (2013) A thermal simulation tool for building and its interoperability through the Building Information Modeling (BIM) platform. Buildings, Vol. 3(2), pp. 380-398.

Banz (undated) Productivity benefits of BIM [Online] http://www.mbie.govt.nz/about/whatshappening/news/document-image-library/nz-bim-productivity-benefits.pdf [12/11/2016].

Blismas N. (2007) Off-site manufacture in Australia: Current state and future directions. Cooperative Research Centre for Construction Innovation: Australia.

Blismas N., Pasquire C. and Gibb A. (2006) Benefit evaluation for off-site production in construction. Construction Management and Economics, Vol. 24 (2), pp. 121-130.

Blismas N. and Wakefield R. (2009) Drivers, constraints and the future of offsite manufacture in Australia. Construction Innovation, Vol. 9 (1), pp. 72-83.

Boyd N., Khalfan M.M.A. and Maqsood T. (2013) Off-site construction of apartment buildings. Journal of Architectural Engineering, Vol. 19(1), pp. 51-57.

Bryde D., Broqutas M. and Volm J.M. (2013) The project benefits of Building Information Modelling (BIM). International Journal of Project Management, Vol. 31 (7), pp. 971980.

buildingSmart UK (2010) Constructing the business case Building information modelling. [Online] http://www.hfms.org.hu/web/images/stories/BIM/FreeReport-BIM.pdf [31/03/2016].

Bynum P., Issa R.R.A. and Olbina S. (2012) Building Information Modelling in support of sustainable design and construction. Journal of Construction Engineering and Management, Vol. 139 (1), pp. 24-34.

Cabinet Office (2011) Government Construction Strategy, UK Government Report, Cabinet Office, London, May.

Cao X., Li X., Zhu Y. and Zhang Z. (2016) A comparative study of environmental performance between prefabricated and traditional residential buildings in China. Journal of Cleaner Production, Vol. 109, pp. 131-143. 
Chan I.Y.S., Leung H.Y., Fung I.W.H. and Leung M. (2016) How can BIM support construction safety management? Development of SIM. MATEC Web of Conferences, Vol. 66 (00018), pp. 1-5.

Charalabidis Y., Gionis G., Hermann K.M. and Martinez C. (2008a) Enterprise Interoperability Research Roadmap, European Commission.

Charalabidis Y.,Panetto H., Loukis E. and Mertins K. (2008b) Interoperability approaches for enterprises and administrations worldwide. The Electronic Journal for E-Commerce Tools and Applications, Vol. 2 (3), pp.1-10.

Chen Y., Okudan G.E. and Riley D.R. (2010) Sustainable performance criteria for construction method selection in concrete buildings. Automation in Construction, Vol. 19, pp. 235-244.

Cirinini A.L.C., Ventura S.M. and Paneroni M. (2016) Implementation of an interoperable process to optimise design and construction phases of a residential building: A BIM pilot project. Automation in Construction, Vol. xxx, pp. xxx-xxx.

Christoforou E., Kylili A., Fokaides P.A. and Ioannou I. (2016) Cradle to site Life Cycle Assessment (LCA) of adobe bricks. Journal of Cleaner Production, Vol. 112 (1), pp. 443452.

Cowles E. and Warner P. (2013) Prefabrication and Modularization in Construction: 2013: Survey results. FMI Corporation

Delcambre B. (2014) Mission Numérique Bâtiment. [Online] http://www.territoires.gouv.fr/IMG/pdf/rapport mission_numerique batiment.pdf [1/12/2014].

Deshpande A. and Whitman J. B. (2014) Evaluation of the use of BIM Tools for construction site utilization planning. $50^{\text {th }}$ ASC Annual International Conference Proceedings. March 26-28, 2014 at Virginia, USA.

Doumbouya L., Gao G. and Guan C. (2016) Adoption of the Building Information Modeling (BIM) for construction project effectiveness: The review of BIM benefits. American Journal of Civil Engineering and Architecture, Vol. 4 (3), pp. 74-79.

Eastman C. and Sacks R. (2008) Relative productivity in the AEC industries in the United States for on-site and off-site activities. Journal of Construction Engineering and Management, Vol. 134(7), pp. 517-526.

Egan, J. (1998). The Egan Report - Rethinking Construction. Report of the construction industry task force to the deputy prime minister. London.

Elnaas H., Gigado K. and Ashton P. (2014) Factors and drivers effecting the decision of using off-site manufacturing (OSM) systems in house building industry. Journal of Engineering, Project and Production Management, Vol. 4(1), pp. 51-58.

El Meouche R., Rezoug M. and Hijazi I. (2013) Integrating and managing BIM in GIS, software review. International Archives of the Photogrammetry, Remote Sensing and Spatial Information Sciences, Volume XL-2/W2, ISPRS 8th 3DGeoInfo Conference \& WG II/2 Workshop, 27 - 29 November 2013, Istanbul, Turkey.

Ezcan V., Isikdag U. and Goulding J. S. (2013) BIM and off-site manufacturing: Recent research and opportunities. Proceedings of International Council for Research and Innovation in Building and Construction (CIB) World Building Congress 2013, $5^{\text {th }}-9^{\text {th }}$ May, 2013, Brisbane, Australia.

Farmer M. (2016) Farmer review 2016: Modernise or die. Commissioned and published by the Construction Leadership Council (CLC), UK.

Giel, B. K. and Issa, R. (2013) Return on investment analysis of building information modeling in construction. Journal of Computing in Civil Engineering, Vol. 27(5), 511-521

Gibb A.G.F. (2001) Standardisation and case study: distinguishing myth from reality using case study research. Construction Management and Economics, Vol.19 (3), pp. 307-315. 
Gibson F. (2012) A new modular paradigm in Building Information Modeling. Bechtel Technology Journal, Vol. 4(1), pp. 1-8.

Gilkinson, N., Raju, P., Kiviniemi, A., and Chapman, C. (2015). Building information modelling: the tide is turning.Proceedings of the Institution of Civil Engineers-Structures and Buildings, Vol.168(2), pp. 81-93.

Gorgolewski M.T. (2004) Prefabrication and sustainability in UK housing. [Online] http://web.ornl.gov/sci/buildings/2012/2004\%20B9\%20papers/174_Gorgolewski.pdf [1/11/2014].

Gong T., Yang J., Hu H. and Xu F. (2015) Construction technology of off-site precast concrete buildings. Frontiers of Engineering Management, Vol. 2(2), pp. 122-124.

Goulding J., Nadim W., Petridis P. and Alshawi M. (2013) Construction industry off-site production: A virtual reality interactive training environment prototype. Advanced Engineering Informatics, Vol. 26(1), pp. 103-116.

Goulding J., Rahimian F.P., Arif M. and Sharp M. (2012) Offsite construction: Strategic priorities for shaping the future research agenda. Journal of Architectoni.ca, Vol. 1 (1). pp. 62-73.

Guo S.-J.and Wei T. (2016) Cost-effective energy saving measures based on BIM technology: Case study at National Taiwan University. Energy and Buildings, Vol. 127, pp. 433-441.

Hairstans R. (2010) Off-site and modern methods of timber construction: A sustainable approach. TRADA Technology Ltd

Hall, K. D. (2006) (Eds) The Green Building Bible: Essential information to help you make your home and buildings less harmful to the environment, the community and your family (3rd Ed), Vol.1. Green Building Press, England.

Ham Y. and Golparvar-Fard M. (2014) Mapping actual thermal properties to building elements in gbXML-based BIM for reliable building energy performance modelling. Automation in Construction, Vol. 49 (Part B), pp. 214-224.

Hamid Z.A. and Kamar K.A.M. (2012) Aspects of off-site manufacturing application towards sustainable construction in Malaysia. Construction Innovation, Vol. 12 (1), pp.4 - 10.

HM Government (2013) HM Government industrial strategy: Construction 2025. [Online] https:/www.gov.uk/government/uploads/system/uploads/attachment data/file/210099/bis13-955-construction-2025-industrial-strategy.pdf [1/11/2014].

HM Government (2013b) Early Adopter Project: Ministry of Justice -Liverpool Local Prison Post Occupancy Evaluation used to update standard kitchen designs. Unclassified Report. [Online] http://www.bimtaskgroup.org/wp-content/uploads/2013/11/Liverpool-PrisonCase-Study-Final-18-11-13-web.pdf [04/09/2016].

HMYOI (2013) HMYOI Cookham Wood houseblock and education building. [Online] http://www.bimtaskgroup.org/wp-content/uploads/2013/07/HMYOI-Cookham-Wood.pdf [15/01/2015].

Hong J., Shen G.Q., Mao C., Li Z. and Li K. (2016) Life-cycle energy analysis of prefabricated building components: an input-output-based hybrid model. Journal of Cleaner Production, Vol. 112, pp. 2198-2207.

Hosseini M.R., Namzadi M.O., Rameezdeen R., Banihashemi S. and Chileshe N. (2016) Barriers to BIM adoption: Perceptions from Australian small and medium-sized interprises (SMES). $40^{\text {th }}$ AUBEA 2016, Radical Innovation in the Built Environment, Cairns, Australia, $6^{\text {th }}-8^{\text {th }}$ July 2016.

Irizarry J., Karan E.P. and Jalaei F. (2013) Integrating BIM and GIS to improve the visual monitoring of construction supply chain management. Automation in Construction, Vol. 31, pp. 241-254. 
Isaac S., Bock T. and Stolíar Y. (2016) A methodology for the optimal modularization of building design. Automation in Construction, Vol. 65, pp. 116-124.

Ismail N.A.A., Drogemuller R., Beazley S. and Owen R. (2016) A Review of BIM Capabilities for Quantity Surveying Practice. MATEC Web of Conferences 66, 00042 (2016), DOI: 10.1051/matecconf/20166 IBCC 2016600042

Jaillon L., Poon C.S., and Chiang Y.H. (2009) Quantifying waste reduction potential of using prefabrication in building construction in Hong Kong. Waste Management, Vol. 29 (1), pp. 309-320.

Jayasena H.A.E.C., Yoosuff M.Y.A.I.M. and Jayasena H.S. (2016) Economies of off-site concrete construction with BIM. The $7^{\text {th }}$ International Conference on Sustainable Built Environment. Earl's Regency Hotel, Kandy, Sri Lanka, 16-18 December 2016,

Ji Y., Li K., Liu G., Shrestha A. and Jing J. (2016) Comparing greenhouse gas emissions of precast in-situ and conventional construction methods. Journal of Cleaner Production. 10.1016/j.jclepro.2016.07.143

Kamali M. and Hewage K. (2016) Life cycle performance of modular buildings: A critical review. Renewable and Sustainable Energy Reviews, Vol. 62, pp. 1171-1183.

Kasim, T., Li, H. and Rezgui, Y. (2012) BREEAM: Based dynamic sustainable building design assessment. Presented at: EG-ICE 2012, Munich, Germany, 4- 6 July 2012.

Kempton J. (2010) Modern methods of construction and RSL asset management: a quantitative study. Structural Survey, Vol. 28 (2), pp.121 - 131.

Khanzode A., Fischer M., Reed D., (2008) Benefits and lessons learned of implementing building VDC technologies for coordination of MEP systems on a large healthcare project. ITcon 13, pp. 324-342

Kim D. (2008) Preliminary life cycle analysis of modular and conventional housing in Benton Harbor. MSc Thesis, University of Michigan, USA.

Koch C. and Firmenich B. (2011) An approach to distributed building modeling on the basis of versions and changes. Advanced Engineering Informatics, Vol. 25 (2), pp. 297-310.

Lawson R.M., Ogden R.G. and Bergin R. (2012) Application of modular construction in high rise buildings. Journal of Architectural Engineering, Vol. 18(2), pp. 148-154.

Lawson M., Ogden R. and Goodier C. (2014) Design in Modular Construction. UK: Taylor and Francis Group.

Lawson R.M., Ogden R.G., Pedreschi R., Grubb P.J. and Ola S. S.O. (2005) Developments in pre-fabricated systems in light steel and modular construction. The Structural Engineer.

Lee H.W., Oh H., Kim Y. and Choi K. (2015) Quantitative analysis of warnings in building information modelling. Automation in Construction, Vol. 97, pp. 55-68.

Lee J. and Kim J. (2017) BIM-Based 4D Simulation to improve module manufacturing productivity for sustainable building projects. Sustainability, Vol. 9(3)

Li C.Z., Hong J., Xue F., Shen G.Q., Xu X. and Luo L. (2016a) SWOT analysis and Internet of Things-enabled platform for prefabrication housing production in Hong Kong. Habitat International, Vol. 57, pp. 74-87.

Li C.Z., Hong J., Xue F., Shen G.Q., Xu X. and Mok M.K. (2016b) Schedule risks in prefabrication housing production in Hong Kong: a social network analysis. Journal of Cleaner Production, Vol. xx, pp. 1-13.

Li J., Hou L., Wang X., Wang J., Guo J., Zhang S. and Jiao Y. (2014) A project-based quantification of BIM benefits. International Journal of Advanced Robotic Systems, Vol. 11. doi: $10.5772 / 58448$.

Linner T. and Bock T. (2012) Evolution of large-scale industrialisation and service innovation in Japanese prefabrication industry. Construction Innovation, Vol. 12 (2), pp. $156-178$. 
Liu H., Altaf M.S., Lei Z., Lu M. and Al-Hussein M. (2015). Automated production planning in panelized construction enabled by integrating discrete-event simulation and BIM. In the proceedings of the ICSC15 - The CSCE International Construction Specialty Conference, Vancouver, Canada, June 7 - 10, 2015.

Love P.E.D. (2002) Influence of project type and procurement method on rework costs in building construction projects. Journal of Construction Engineering and Management, Vol. 128 (1), pp. 18-29.

Love P., Edwards D. and Irani Z. (2011) Moving beyond optimism bias and strategic misrepresentation: An explanation of social infrastructure project cost overruns. IEEE Transaction on Engineering Management.

Lu N. and Korman T. M. (2010) Opportunities for advancement of modular construction projects using Building Information Modelling (BIM). In: American Society of Construction 2010 Conference Proceeding, Boston, MA. US, 2010.

Lu W., Fung A., Peng Y., Liang C. and Rowlinson S. (2014) Cost-benefit analysis of Building Information Modeling implementation in building projects through demystification of time-effort distribution curves. Building and Environment, Vol. 82, pp. 317-327.

Malekitabar H., Ardeshir A., Sebt M.H. and Stouffs R. (2016) Construction safety risk drivers: A BIM approach, Safety Science, Vol. 82, pp. 445-455.

Mao C., Shen Q., Shen L. and Tang L. (2013) Comparative study of greenhouse gas emissions between off-site prefabrication and conventional construction methods: Two case studies of residential projects. Energy and Buildings, Vol. 66, pp. 165-176.

Mao C., Xie F., Hou L., Wu P., Wang J. and Wang X. (2016) Cost analysis for sustainable off-site construction based on a multiple case study in China. Habitat International, Vol. 57, pp. 215-222

Memon A.H., Abdul-Rahman I., Zainun N.Y. and Abd-Karim (2013) Web-based risk assessment technique for time and cost overrun (WRATTCO)-A framework. ProcediaSocial Behavioural Sciences, Vol. 129, pp. 178-185.

Miles J. and Whitehouse N. (2013) Off-site housing review. Construction Industry Council, UK.

Mitchell C.A. and Keaveney M. (2013) An examination of the potential of Building Information Modelling to increase the efficiency of Irish contractors on design and build projects. International Virtual Conference, 25-29 March 2013, University of Zilina, Slovakia

Musa A.M., Abanda F.H., Oti A.H., Tah J.H.M. and Boton C. (2016) The potential of 4D modelling software systems for risk management in construction projects. $20^{\text {th }}$ CIB World Building Congress 2016, May 30 - June 3, Tampere, Finland.

Musa A.M., Abanda H. and Oti H. (2015) Assessment of BIM for managing scheduling risks in construction project management. CIB W78 conference, 27-29 October, 2015, Eindhoven, The Netherlands.

Nadim W. and Goulding J.S. (2010) Offsite production in the UK: the way forward? A UK construction industry perspective. Construction Innovation, Vol. 10 (2), pp.181 - 202.

Nadim W. and Goulding J.S. (2011) Offsite production: A model for building down barriers: A European construction industry perspective. Engineering, Construction and Architectural Management, Vol. 18 (1), pp. 82-101.

Nawari N.O. (2012) BIM standard and off-site construction. Journal of Architectural Engineering, Vol. 18 (2), pp. 107-113.

NBIMS (2015) About the national BIM standard-United States. [Online] http://www.nationalbimstandard.org/about.php [15/01/2015].

NBS (2014) NBS BIM object standard. [Online] 
http://www.nationalbimlibrary.com/Content/BIMStandard/NBS-BIM-Object-Standardv1 1.pdf $[24 / 11 / 2014]$.

NHBC (2006) A guide to modern methods of construction. BRE Press, UK.

Oesterreich T.D. and Teuteberg F. (2016) Understanding the implications of digitisation and automation in the context of industry 4.0: A triangulation approach and elements of a research agenda for the construction industry. Computers in Industry, Vol. 83, pp. 121139.

Oti A. H., Tizani W., Abanda F. H., Jaly-Zada A. and Tah J. H. M. (2016) Structural sustainability appraisal in BIM. Automation in Construction, Vol. 69, pp. 44-68.

Owolabi A.A., Anumba C.J. and El-Hamalawi A. (2003) Towards implementing integrated building product libraries. Construction Innovation, Vol. 3 (3), pp. 175-194.

Palos S., Kiviniemi A. and Kuusisto J. (2013) Future perspectives on product data management in Building Information Modelling. Construction Innovation, Vol. 14 (1), pp. $52-68$.

Pan W., Gibb A.G. and Dainty A.R. (2012) Strategies for integrating the use of off-site production technologies in house building. Construction Engineering and Management, Vol. 138 (11), pp. 1331-1340.

Pan W. and Goodier C. (2012) Housebuilding business and off-site construction take-up. Journal of Architectural Engineering, Vol. 18(20), pp. 84-93.

Patlakas P.,Livingstone A. and Hairstans R.(2015b)A BIM platform for offsite timber construction.In: Education and Research in Computer Aided Architectural Design in Europe, 16-18 Sept 2015, Vienna, Austria.

Patlakas P., Menendez J. and Hairstans R. (2015a) The potential, requirements and limitations of BIM for offsite timber construction. The International Journal of 3-D Information Modeling, Vol. 4(1), pp. 54-70.

Papadonikolaki E.,Vrijhoef R. and Wamelink H. (2016) The interdependences of BIM and supply chain partnering: empirical explorations. Architectural Engineering And Design Management Vol. 0, Iss. 0, 0

Postnote (2003) Modern methods of construction, Parliamentary Office of Science and Technology, UK, No 209, December 2003 [Online] http://www.parliament.uk/documents/post/postpn209.pdf [04/09/2016].

Quale J., Eckelman M.J., Williams K.W., Sloditskie G. and Zimmerman J.B. (2012) Construction matters: comparing environmental impacts of building modular and conventional homes in the United States. Journal of Industrial Ecology, Vol. 16 (2), pp. 243-253.

Reizgevičius M., Ustinovičius L. and Rasiuslis R. (2013) Efficiency evaluation of 4D CAD model. Procedia Engineering, Vol. 57, pp. 945-951.

Rezaei R., Chiew T.K., Lee S.P. and Aliee Z.S. (2014a) A semantic interoperability framework for software as a service systems in cloud computing environments. Expert Systems with Applications, Vol. 41 (13), pp. 5751-5770.

Rezaei R., Chiew T.K., Lee S.P. and Aliee Z.S. (2014b) Interoperability evaluation models: A systematic review. Computers in Industry, Vol. 65 (1), pp. 1-23.

Rogan A.L., Lawson R.M. and Bates-Brkljac N. (2000) Value and benefits assessment of modular construction. Steel Construction Institute, UK.

Ross, K. (2005) Achieving best practice in modern methods of construction. Building Research Establishment, UK.

Said H. and El-Rayes K. (2014) Automated multi-objective construction logistics optimization system. Automation in Construction, Vol. 43, pp. 110-122.

Samarasinghe T., Mendis P., Ngo T. and Fernando W.J.B.S. (2015) BIM software framework for prefabricated construction: Case study demonstrating BIM implementation on a 
modular house. $6^{\text {th }}$ International Conference on Structural Engineering and Construction Management, Kandy, Sri Lanka, 11-13 ${ }^{\text {th }}$ December 2015.

Sawhney A., Agnihotri R. and Paul V.K. (2014) Grand challenges for the Indian construction industry. Built Environment Project and Asset Management, Vol. 4(4), pp. 317 - 334.

Schünmann D. (2013) BIM: Seize the opportunity for your business. [Online] http://www.bimtaskgroup.org/wpcontent/uploads/2013/07/BIMsupplement2013 download_v2.pdf [30/11/2014].

Sebastian R., Haak W. and Vos E. (2009) BIM application for integrated design and engineering in small scale housing development: A pilot project in the Netherlands. Future Trends in Architectural Management, International Symposium CIB-W096 2009 Taiwan November 02-04, 2009, Tainan, Taiwan.

Sen S. (2012) The impact of BIM/VDC on ROI - Developing a financial model for savings and ROI calculation of construction projects, MSc thesis, Department of Real Estate and Construction Management, KTH Architecture and the Built Environment.

Shade J., Olofsson T. and Schreyer M. (2011) Decision-making in a model- based design process. Construction Management and Economics, Vol. 29 (4), pp. 371-382.

Shadram F., Johansson T.D., Lu W., Schade J. and Olofsson T. (2016) An integrated BIMbased framework for minimizing embodied energy during building design. Energy and Buildings, Vol. 128, pp. 592-604.

Shehu Z., Holt G.D., Endut I.R. and Akintoye A. (2015) Analysis of characteristics affecting completion time for Malaysian construction projects. Built Environment Project and Asset Management, Vol. 5(1), pp. 52-68.

Shen Z. and Issa R.R.A. (2010). Quantitative evaluation of the BIM-assisted construction detailed cost estimates. Journal of Information Technology in Construction, Vol 15, pp. 234-257.

Stanley R. and Thurnell D. (2014) The benefits of, and barriers to, implementation of 5D BIM for quantity surveying in New Zealand. Australasian Journal of Construction Economics and Building, Vol. 14 (1), pp. 105-117.

Steinhardt D.A. and Manley K. (2016) Adoption of prefabricated housing-the role of country context. Sustainable Cities and Society, Vol. 22, pp. 126-135.

Suermann P.C. and Issa R.R.A. (2009) Evaluating industry perceptions of Building Information Modelling (BIM) impact on construction. ITcon, Vol. 14, pp. 574-594.

Tam V.W.Y., Fung I.W.H., Sing M.P. and Ogunlana S.O. (2015) Best practice of prefabrication implementation in the Hong Kong public and private sectors. Journal of Cleaner Production, Vol. 109, pp. 216-231.

Tan X., Hammad A. and Fazio P. (2010) Automated code compliance checking for building envelope design. Journal of Computing in Civil Engineering, Vol. 24(20, pp. 203-211.

The HM Government (2013) Procurement trial case study: Cookham Wood Prison [Online] https://www.gov.uk/government/publications/procurement-trial-case-study-cookhamwood-prison [30/11/2014].

Vernikos V.K (2012) Optimising Building Information Modelling and off-site construction for civil engineering. Civil Engineering, Vol. 165 (CE4), pp. 147.

Vernikos V.K., Goodier C.I., Broyd T.W., Robery P.C. and Gibb A.G.F. (2014) Building Information Modelling and its effect on off-site construction in UK civil engineering. Proceedings of the ICE - Management, Procurement and Law, 167 (MP3), pp. 152 - 159.

Waskett P. (2001) Current practice and potential uses of prefabrication. DTI Construction Industry Directorate Project Report. Department of Trade and Industry, UK.

Warszawski A. (1999) Industrialized and automated building systems. E. \& F.N. Spon, London. 
Won J., Cheng J.C.P. and Lee G. (2016) Quantification of construction waste prevented by BIM-based design validation: Case studies in South Korea. Waste Management, Vol. 49, pp. 170-180.

Wong J.K.-W. and Kuan K.-L. (2014) Implementing 'BEAM Plus' for BIM-based sustainability analysis. Automation in Construction, Vol. 44, pp. 163-175.

Wong F.W.H., Lam P.T.I., Chan E.H.W. and Shen L.Y. (2007) A study of measures to improve constructability. International Journal of Quality \& Reliability Management, Vol. 24, pp. 586-601.

Wong, K.-D and Fan, Q. (2013). Building information modelling (BIM) for sustainable building design. Facilities, Vol. 31(3/4), 138-157.

Yates J.K. (2013) Sustainable methods for waste minimisation in construction. Construction Innovation, Vol. 13 (3), pp.281 - 301.

Yunus R. and Yang J. (2012) Critical sustainability factors of industrialised building systems. Construction Innovation, Vol. 12 (4), pp. 447-463.

Yunus R. and Yang J. (2014) Improving ecological performance of industrialized building systems in Malaysia. Construction Management and Economics, Vol. 32 (1-2), pp. 183195.

Zanni M.A., Soetanto R. and Ruikar K. (2014) Defining the sustainable building design process: Methods for BIM execution planning in the UK. International Journal of Energy Sector Management, Vol. 8 (4).

Zenga M. and Javor A. (2008) Modular homes: The future has arrived. ISBN-10: 1604140674, Cronos Press

Zhang S., Teizer J., Lee J.-K., Eastman C.M. and Venugopal M. (2013) Building Information Modeling (BIM) and safety: Automatic safety checking of construction models and schedules. Automation in Construction, Vol. 29, pp. 183-195.

Zhang C., Zayeb T., Hijazi W. and Alkass S. (2016) Quantitative assessment of building constructability using BIM and 4D simulation. Open Journal Civil Engineering, Vol. 6, pp. 442-461. 